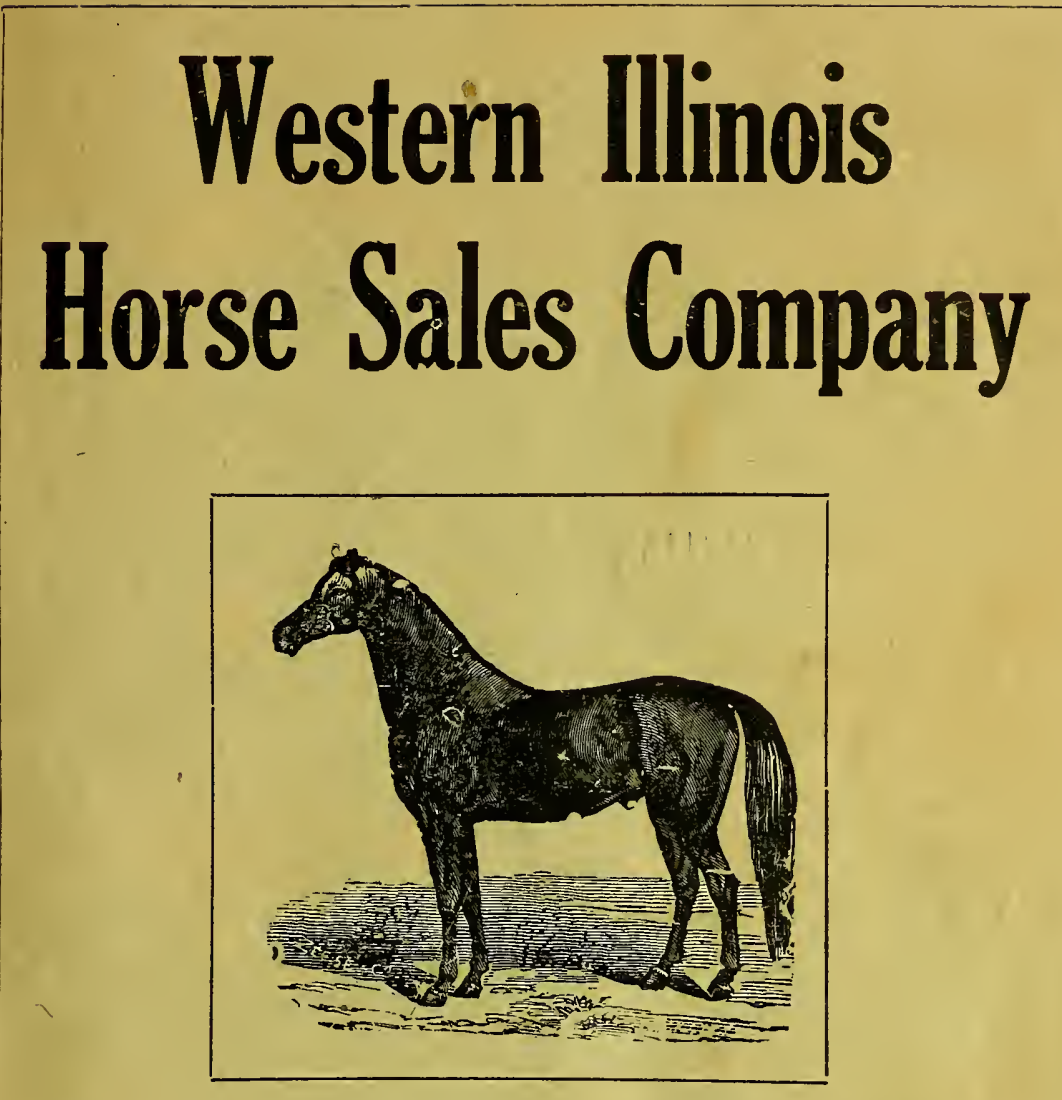

Auction Sale Light Harness Horses AT THE FAIR GROUNDS

Macomb, Thursday, Mar. 13 3ra

Commencing at 12 0'clock Noon, Sharp 



\section{SEE THE GOOD ONES}

ATTEND THE

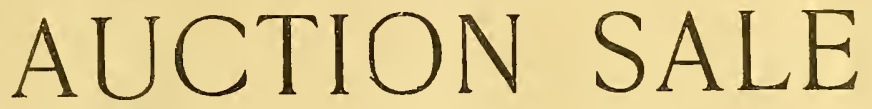

OF

LIGHT HARNESS

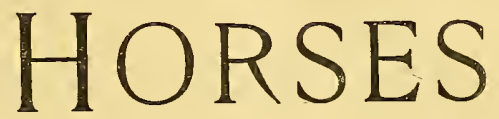

TO BE HELD AT THE

FAIR GROUNDS

MACOMB, ILL., THURSDAY, MARCH I 3, I9I3

SALE COMMENCING PROMPTLY AT I 2 O'CLOCK NOON

COL, R. N. WEAR,
COL. "TIP" GREE, $\}$ Auctioneers

WESTERN ILLINOIS HORSE SALES CO.

Animals will be sold in the order designated in this catalog. There will be NO deviation from this order. NO SUBSTITUTE animals will be offered in place of horses regularly catalogued.

JOURNA L PRINTING CO., PRINTERS, Maccmb, III. 


\section{Of Importance to Bidders}

This sale will be condusted under the following

\section{TERMS AND CONDITIONS}

Each animal offered will be sold without reservation (unless publicly stipulated to the contrary) under the following conditions, to-wit:

TERMIS-This sale is for cash, 25 per cent to be paid immediately after the animal is solä, or the sale may be declared void, at the option of the seller. The balance of the purchase money must he paid, or secured, on the same day, or the deposit so made will be forfeited as agreed damages. All payments must be made to the cashier of the sale, for in no case will payments to the consignor entitie the purchaser to obtain the stock. On final payment for an animal the cashier of the sale will issue an order for presentation to the superintendent of stalls for the delivery of the animal so paid for, which orders buyers are cautioned not to lose. Buyers assume all risks and expenses on animals incurred after they are struck down.

BUTERS WILI, PROVIDE THEVSELNES WITH CURRENCY, BANK EXCHANGE, OR BANK REFERENCE.

WARRAVTIES-The name of the owner, who is the responsible party, is given with each entry, and ali representations are made by him. All remarks of the consignor at the time of the sale as to a guarantee of any character, correction of catalogue, etc., will be noted in the auctioneer's record at the same time, and all settlements will be made in accordance therewith. This company will announce, when known, any turf penalty in force on the animal offered, but will assume no liability by reason of any penalty, whether such announcement is made or not. Where consignors report the futuriay engagements of youngsters, a memorandum is printed under the name of each animal. On these engagements, no liability is assumed by the jurcinaser and further payments to continue eligibility to the events are optional with the purchaser.

BLIERS ARE, THEREFOIE, CATTIONED TO PAY ATTEN. TION TO THE ANNOCNCEMENTS FROM THE ACCTIONEER'S STAND.

CHAILENGES-All animals will be sold "as they stand," as respects soundness, the eyes and the wind being guaranteed by the consignor unless otherwise announced by the auctioneer. Any vice, 
however, is subject to challenge. All sales, therefore, will be binding unless a representation be challenged on grounds other than where the soundness of the anjmal is involved. No liability, lezal or otherwise, is assumed by the Western Illinois Horse Sale Company from either party in consequence of any representation or challenge, and, after fuli payment for the animal and its delivery tc the buyer, no warranty of the sesler can be challenged through the Western Illinois Horse Sale Company.

WE ACT AS AGLNTS SIMPLI AND SHALC ENBEAVOR TO PROTECT THE INTERLS'S OF RO'TH, SELLER AND BUYER.

BIDS-No bids less than $\$ 5.00$ will be accepted. The highest bidder to be the buyer; aud if any dispute arises between two or more bidders, the aninal in dispute shall be immediately put up again for advance bids. If there be no advance, then the animal shall go to the person from whom the auctioneer recognized the last bid. No bids will be recıgnized from intoxicated or disorderly parties.

\section{SPECIAL NOTICE.}

Purchasers are earnestly lequested, for their own protection, to comply strictly with lle foregoing conditions of the sale, but should they fail to take advantage of the conditions, adopted main15 for their protection, they waive all recourse thereafter. Bidders are cautioned to comply with the laws of the state regarding auction sales and are hereby warned against bidding unless prepared to comply with the foregoing conditions. Animals resold, owing to the dereliction of the bidder, are sold for the accoint of the party defaulting, who will be liable for the commission charges of this company and other liabilitıes.

HORSES TO BE SOLD WILL BF AT THE SALE BARN PRIOR TO THE DAY OF THE SAIE ANU BUYERS ARF INVTTED TO COME AND EXAMINE THEM.

Prospective buyers should go to the grounds early and examine the horses carefully. The grooms in charge are instructed to show any horse on request, and will gladly do so.

Horses consigned are mined over te the Western Illinois Horse Sales Company, but can be shown by the consignor, and after they are knocked down are to bo rerurned to the company, and will be held by them until paid for by the purchaser, when a release slip is given the buyer which must be presented to the stall manager. 
Slusher Phone No. 50 Main 117 South Side Square

\title{
J. W. CAMPBELL
}

DEALER IN

Hardware, Stoves, Bicycles And Farming Implements

John Deere Gangs

Deere Cultivators

Hays Cultivators and Planters

Deere No. 99 Planters

Deering Binders and Mowers

Emerson Mowers and Rakes

Everything in Farm Machinery

\section{Builders Hardware a Specialty}

\author{
Yours for Service
}

J. W. CAMPBELI MACOMB, ILLINOIS 


\section{No. 2 q O. PARKVILLE JR. 47583}

Trotter. Bay horse. Stands 16 hands; weighs 1150 pounds. Standard and registered. Consigned by F. C. Caine, Galesburg, Il1.

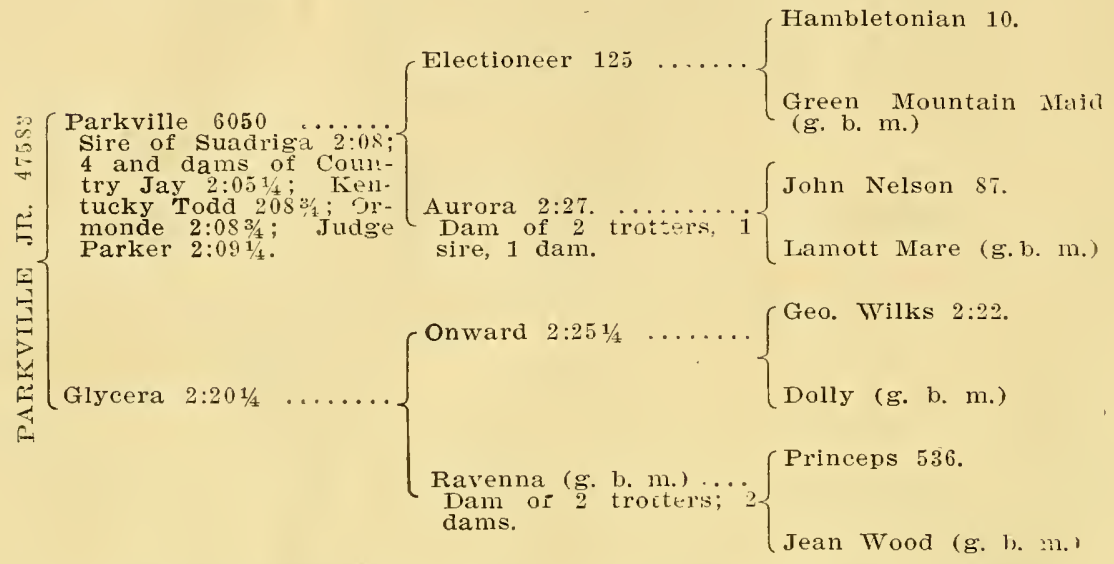

Owner's Statement-Parkville, Jr., is a beautiful bright bay stallion: stands about 16 hands and weighs 1150 pounds. He is a good breeder and sure foal getter. He is perfectly sound and smooth and has trotted a mile in $2: 19 \frac{1}{4}$, and is a good gaited one with perfect manners. A pleasant horse to handle or to use in any way or place. Hasn't a bad habit of any kind. He is a grand bred one for a stock horse and would be a useful horse to race, besides being one of the most perfect and pleasant horses on the road to be found.

\section{No. $3 / 5 \times$ MAY SWIFT BELL}

Bay mare. Trotter. Foaled 1908. Consigned by F. C. Caine,

Galesburg, III.

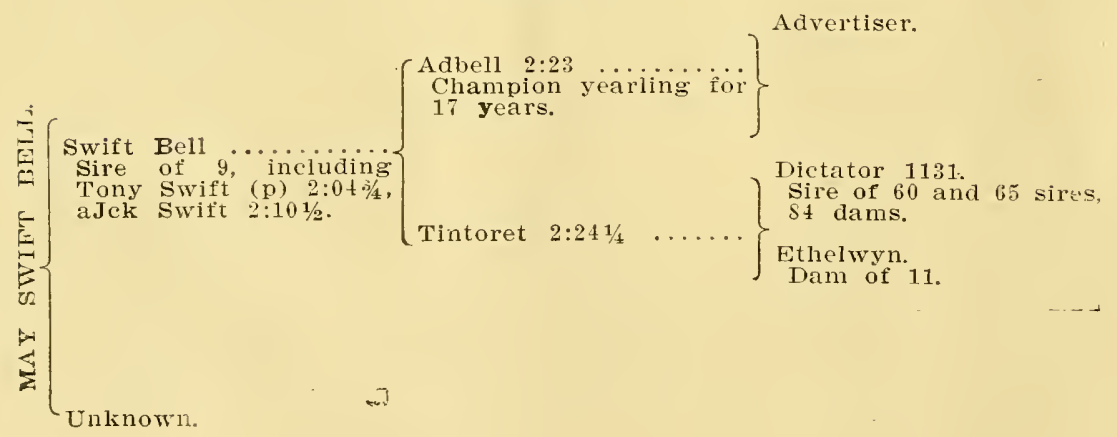


Owner's Statement-Fine driver; city broke; good style; fine disposition. This mare will make an excellent single or double ariver, and good enough to train. Her dam, believed to be a high bred trotting mare, was shipped from Wisconsin to be bred to Swift Bell at North Henderson, 111. Her owner allowed her to be sold for the breeding and feed blll, and her breeding was lost track of. Her owner was never afterwards located. This mare shows that she is a high bred one.

Diamonds, Watches, Clocks, Jeweiry, Silverware
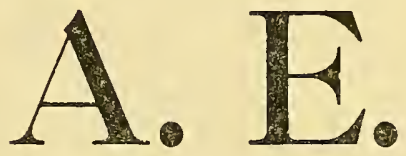
$\int \stackrel{0}{a} \times$ and
Fine Repairing and Engraving Expert Optician

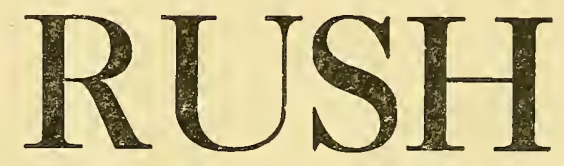

Optician

\section{Stop Watches, a Large Selection..}

North Side Square

Macomb, Illinois

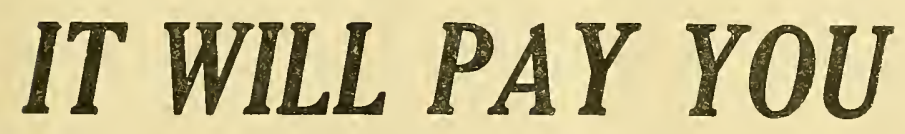

To Patronize the Merchants Whose Advertisements Appear in this Catalogue. 


\section{No. $4 / 5$ LELA BROWN}

Trotter. Foaled 1904. Chestnut sorrel mare, eligible to register. Bred by Dan Brown, Chicago. Consigned by A. M. Woods, Augusta, Ill.

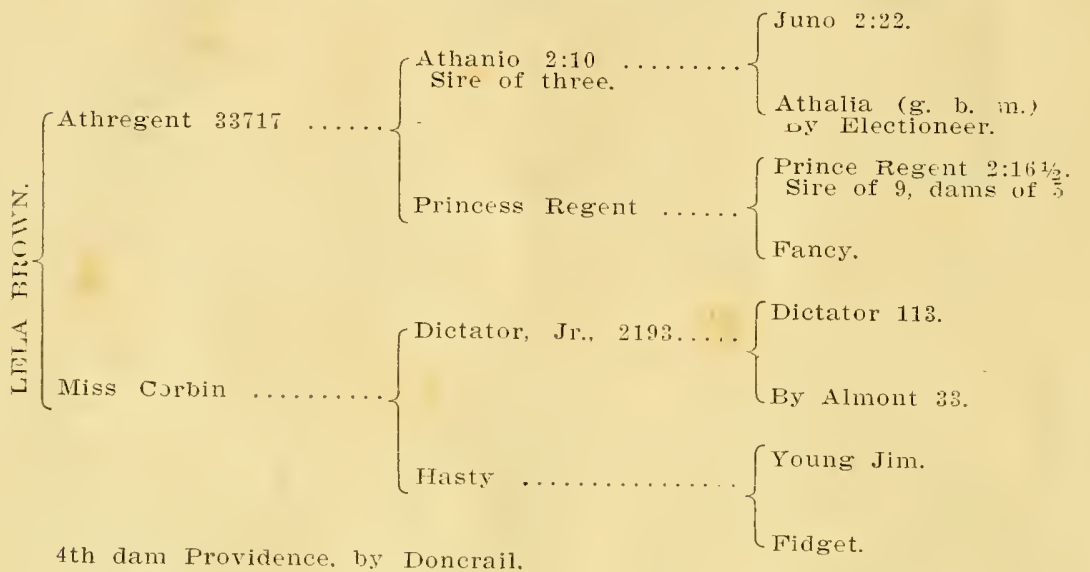

Owner"s Statement-Lela Brown is a handsome chestnut mare; stands about 15.1, with good conformation. She has a nice way of going: steps aell, and was trained for about 90 days. She showed remarkable speed aild stepped a mile in $2: 26 \frac{1}{2}$, last half in $1: 11 \frac{1}{2}$ and an eighth in 16 seconds. She is akind driver. has beautiful all-round action and is not afraid of automobiles. 


\section{No. $5 / 4$ × EARL OF AUGUSTA}

Trotter. Standard and registered. Sorrel gelding, foaled 1908. Bred and consigned by A. M. Woods, Augusta, Ill.

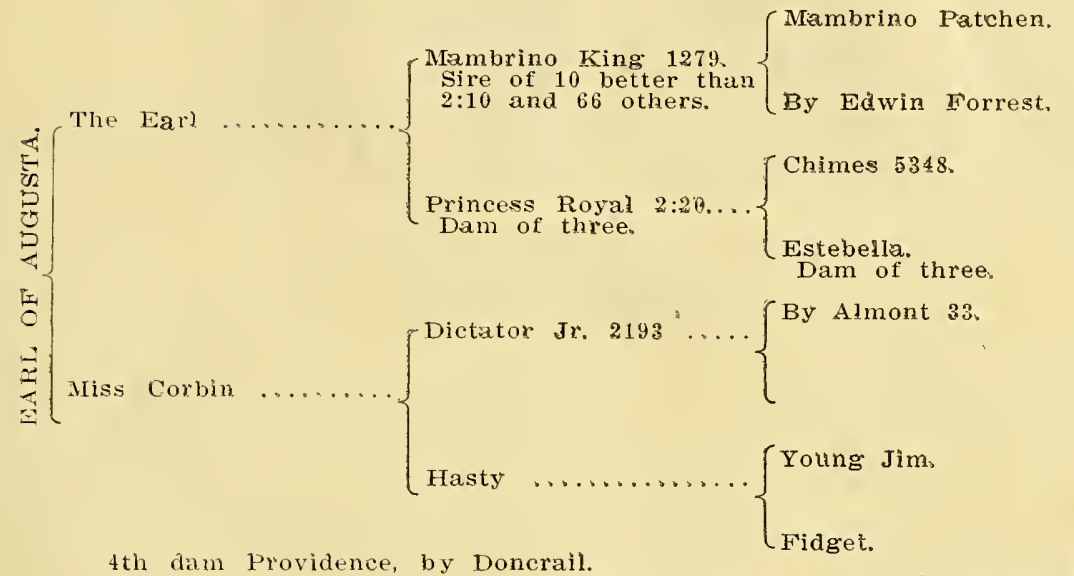

Owner's Statement-Earl of Augusta is a handsome, toppy, high̀ going fellow, with good bone; stands about 15.2. He has never been worked for speed, being just nicely broken. He shows remarkable speed at the end of the halter, and there is no doubt but. what he would make a good race horse if given the opportunity. He has shown kind in all his handling; is not afraid of automobiles, and will make an excellent horse for the matinees, if you don't want a racing prospect. 


\section{NEW LOCATION}
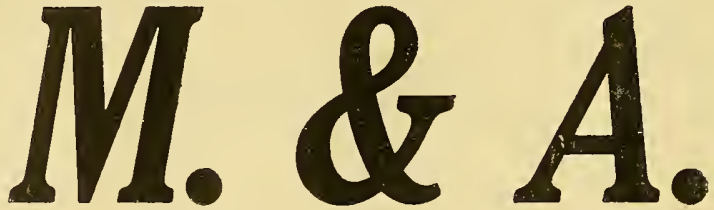

\section{GARAGE}

We have purchased Stocker's newly equipped garage opposite the park and just south of the Pace Hotel. This, with our old stand, makes us better prepared than ever to handle general Automobile repairs.

\section{Full Line of Accessories. .}

Tires, Sundries, Oil, Gasoline, Etc.
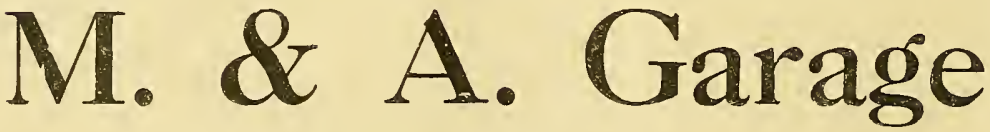

Both Phones

MACOMB, ILLINOIS 


\section{No. $6 / 20$ PEARL EARL}

Trotter. Bay filly; foaled 1909. Eligible to register. Bred and con* signed b̀y A. M. Woods, Augusta, Ill.

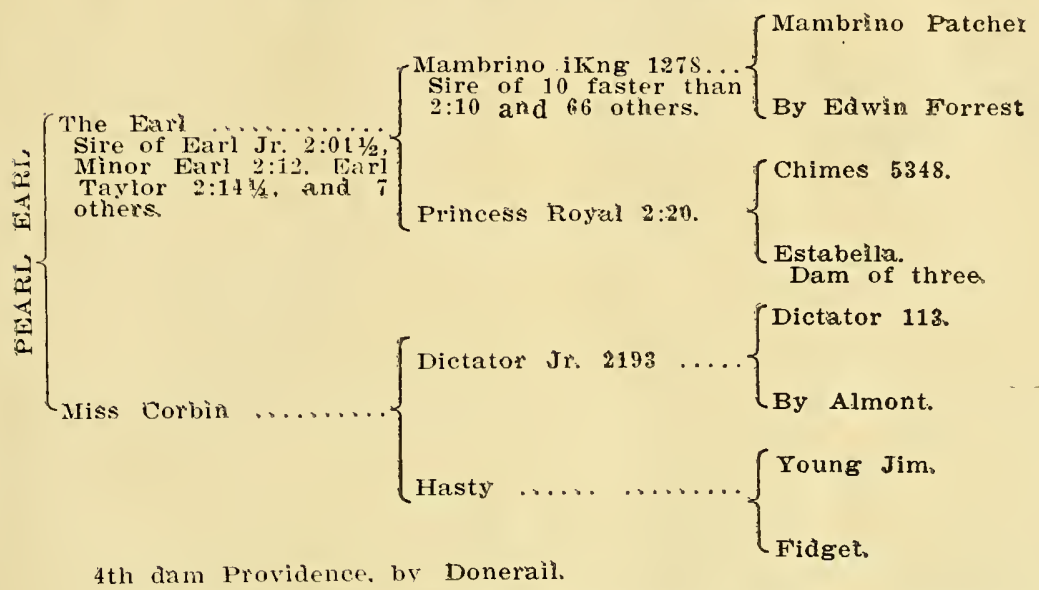

Owner's Statement-Pearl Earl is a nice, blocky filly; has never been broken, but shows weil as a lot trotter. She is of good bone and good disposition, and should make a nice road mare if she does not develop inte something faster. 


\section{No. 7 BROWNLIGHT}

Trotter. Bay colt, foaled 1911 . Eligible to register. Bred and consigned by A. M. Waods, Augusta, III.

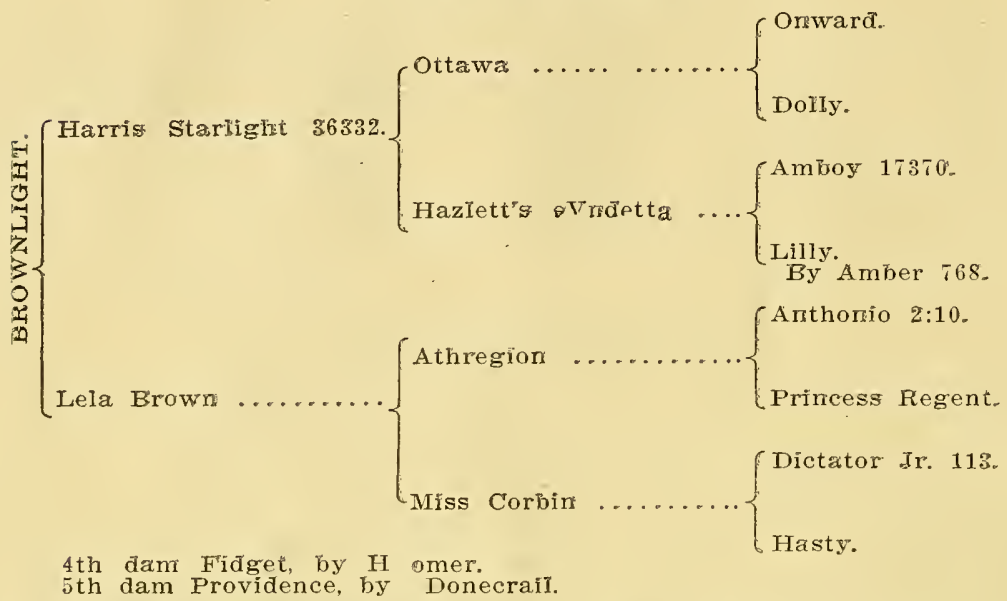

Owner's Statement-Brownlight is a fine, bỉg coltt; is halter broker only, and has never been handled for speed, but shows well as a lot trotter. He steps out well and is a promising youngster, and with his breeding should keep inproving as he is handled.

\section{No. 8 SOLE HEIR}

Pacer. Bay horse, foaled 1908. Stands 15.3. Weighs 1100 pounds.

Bred and consigned by J. B. Ewing, Blardinsville, nll.

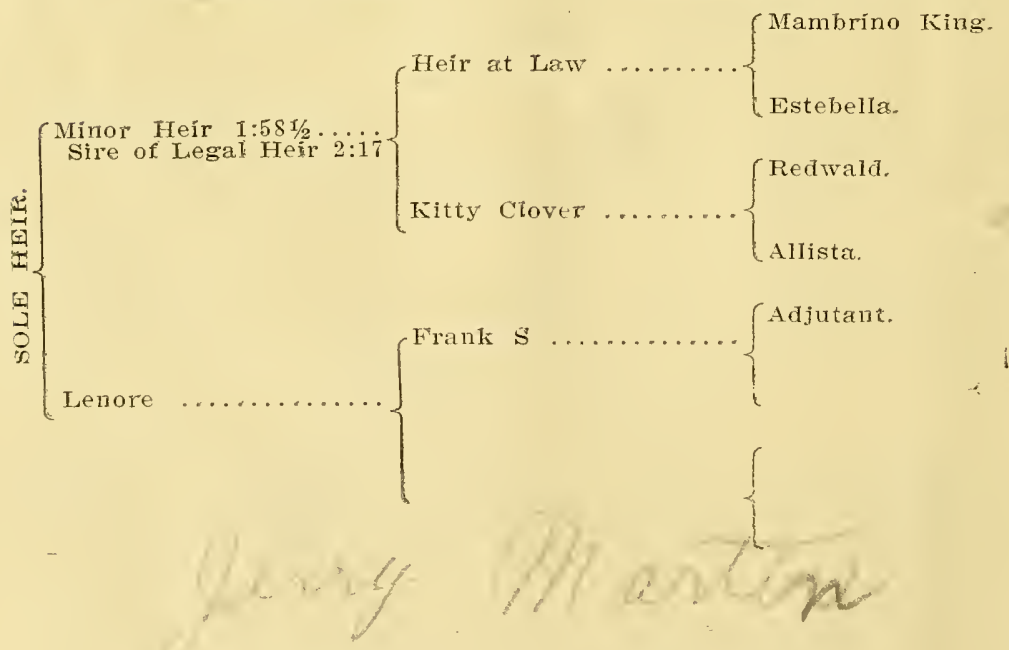


Owner's Statement-Sole Heir is a fine looking, dark bay stallion; absolutely sound. He has never been trained but little, but has shown his ability to pace fast. He has the finest disposition; is fearless on the road; a sure foal-getter, and no doubt will be a great sire. Is sold for no fault. I have too many stalions.

\section{No. 9}

MAC GR ATH 56729

Trotter. Brown colt. Foaled 1911. Bred by Iron Mountain Farm. Iron Mountain, Mo. Consignea by Chas. S. Harris, Galesburg, Ill.

Standard and registered.

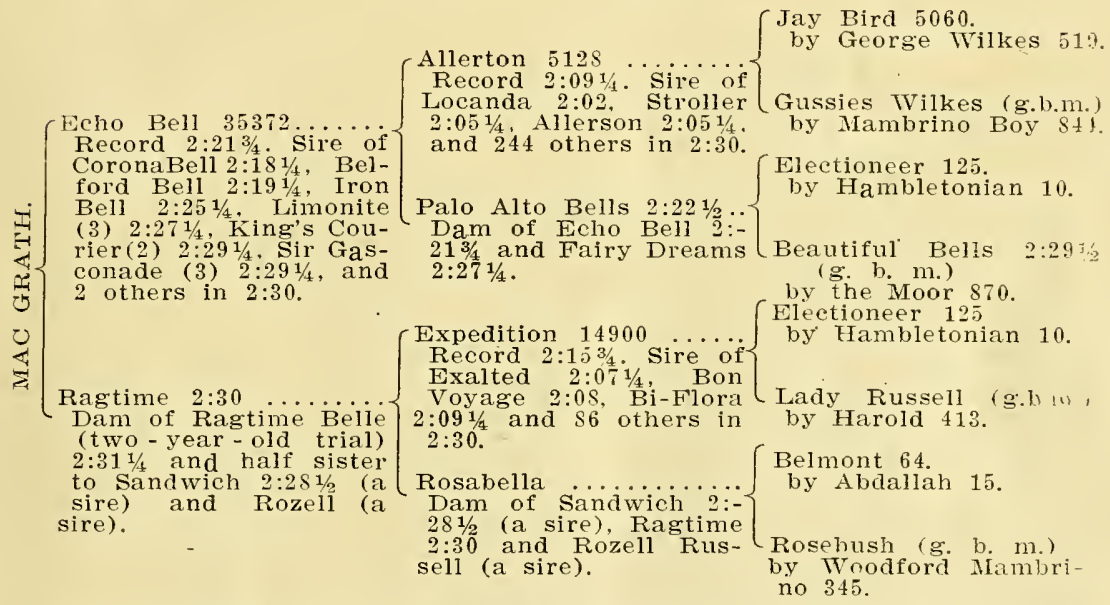

Fosebush is the dam of Chichester $2: 251 / 4$ (sire of Robert J. $2: 113 / 4$ and nine others in 2:30), Extractor (sire of 2 in 2:30), Fairthorn (sire of 7 in 2:30), Pelletier (sire of 15 in 230 ), Rosabella (dam of Sandwich $2: 281 / 2$ and Ragtime $2: 30$ ) and Rosebay (dam of Ruth Ailerton $2: 26$ ).

Expedition 14900, record $2: 153 / 4$, sired the dams of Jack Leyburn 2:04 1/4, Baron Reaper 2:091/4, Charmond 2:101/4, Peter Chimes 2:1.1 $1_{1}$, II Iss Red Chute $2: 14 \% / 4$, Kereri 2:15, Dutchland 2:15 1/2, Bessie Maulin (3) $2: 15 \frac{1}{2}$, Royal Expedition $2: 16 \frac{1}{4}$, Sally Rau $2: 16 \frac{3}{4}$, Fritz (3) 2:$17 \frac{1}{4}$, and 24 others in $2: 30$.

Echo Bell has two daughters (Corona Bell and Belford Bell) that are Grand Circuit timber for 1913.

Owner's Statement-Mac Grath is a corking good colt, a good gaited one, and shows enough to high-wheel cart to insure a high-class trotter. He is good enough to get ready for the three-year-old trots in 1914. 


\section{No. 10 GALE J. S. 42061}

Bay horse. Foaled 1902. Bred by J. S. Butty, Libertyville, Ill. Consigned by J. D. Tabler, Plymouth, Ill.

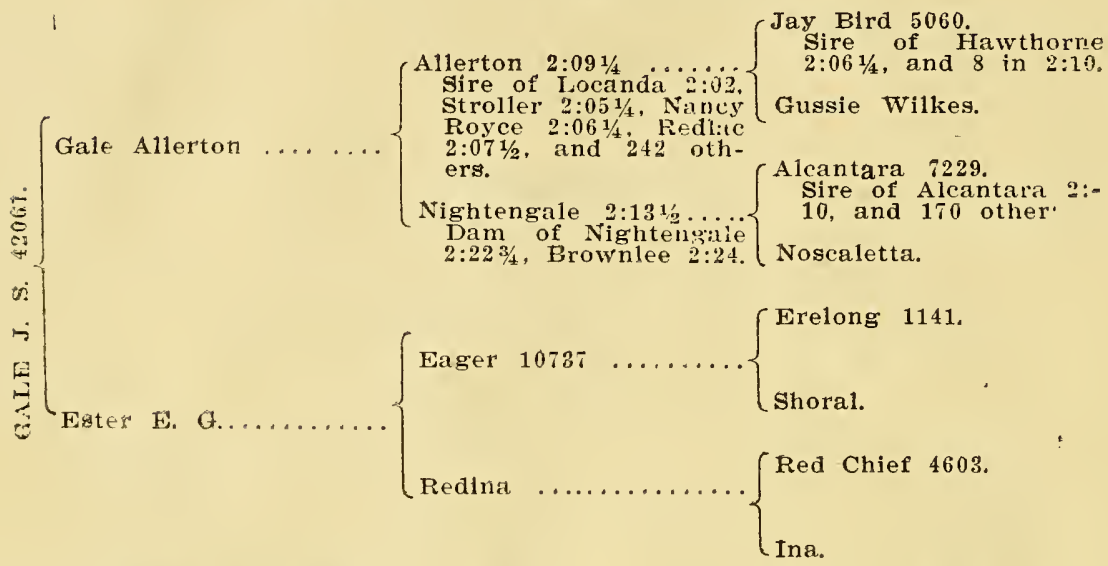

Owher's Statement-The secret of "It's always a Jay Bird" is well understood by those acquainted with his descendants, the Allertons along with the rest. It is their super-vitality first of all-this with their wonderfuj speed conformation and disposition to stick to their gait, makes this the greatest of all harness horse families. This is a family that stays sciund in training and never quits on the home stretch. They cross uniformly well with the other great families, as proven by the records. No other sire approaches Allerton, with his 246 in the list, including Laconda 2:02, also Stroller 2:05 1/4, the fastest new trotter ont last year. Gale J. $S$ of this consignment is probably as well bred as any grandson of Allertoll. il not the best bred. Combining, as he does, the blood of Allerton and Alcantara on his sire's side, with that of Belmont, Nutwood, Red Wilkes, and Dictator on his dam's side. Gale J. S. will prove his worth in proportion to his breeding, if given a fair chance on the track and in the stud. He has had no track work, but has been driven quite a good dea! to buggy. He is a prolific sire and his colts are a sound lot, with guod size and big gaited.

If you are a member of the Driving Club you cain get a winner in this catalogue. 


\section{No. $11 / 0$ C ELECTRIC}

Cinestnut Colt. Foaled 1911. Standard and registered. Consigned by Joe Pine, Galesburg, Ill.

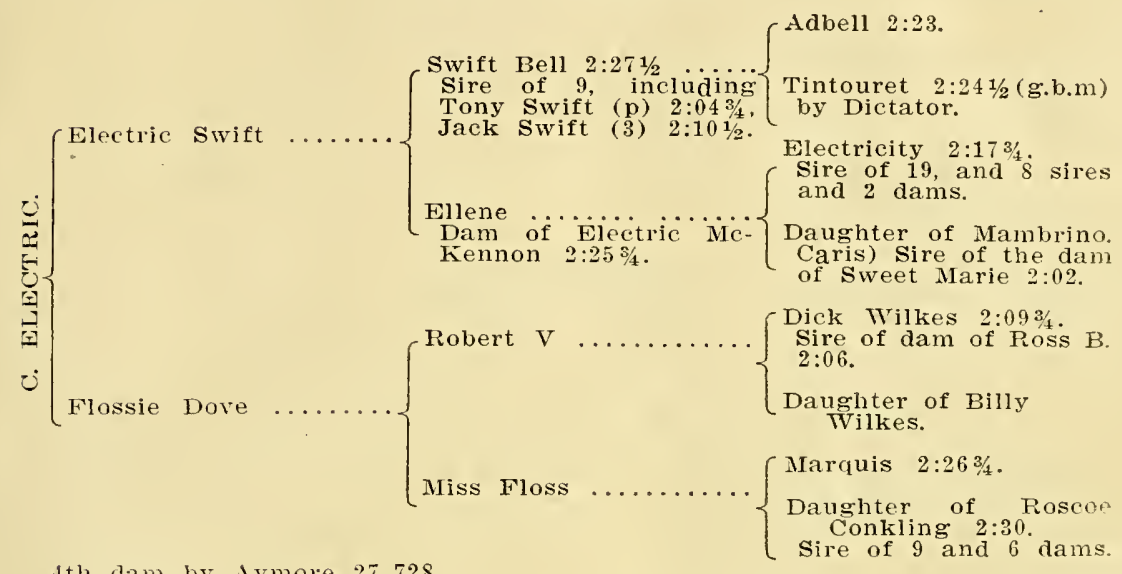

4th dam by Aymore 27 728.

Ownel's Statement-I consider this colt the making of a high class trotter with a little more work. He was worked six weeks in 1912, and including breaking he learned to trot an eighth in : $21 \frac{1 / 4}{4}$. He is city broke and a very nice colt.

If you are a memher of the Dhiving club you cail get a witner in this catalogue. 


\section{No. 12}

\section{CLAUDIA}

Public Trial 2:22.

Pacer. Bay mare. Foaled 1903. Bred by A. V. Brooking, Macomb, Ill. Consigned by Wallace Fellheimer, Macomb, Ill.

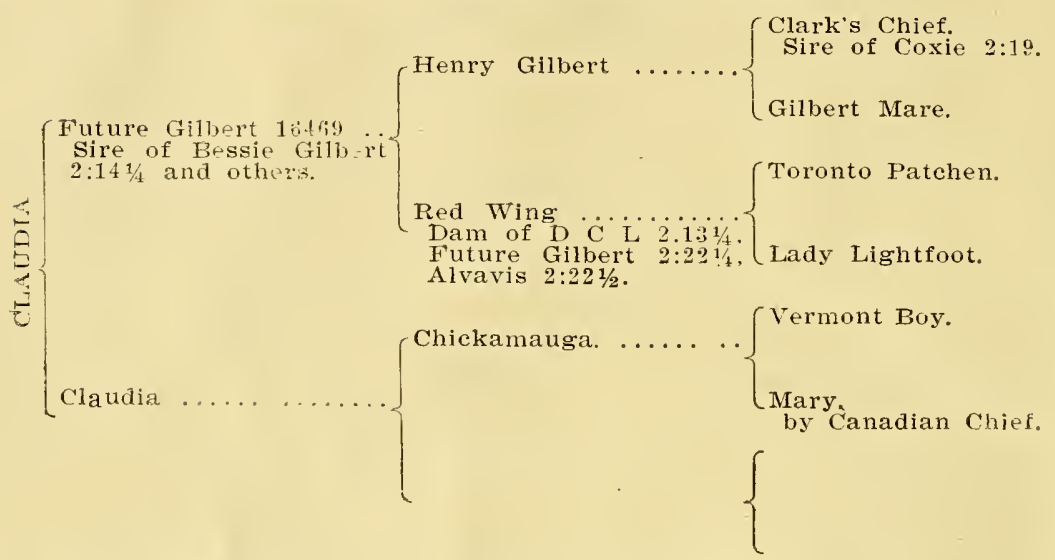

Claudia's dam was a high-class road mare, purchased in the west, and her breeding was lost. She was a mare of quality, and considered one of the best road mares in the county.

Owner's Statement-Claudia is a good-sized, nice, clean, breedylooking mare. She was worked as a 4 -year-old and had lots cf speed, showing a public trial of $2: 22$. For the past few years she has been used for a family mare, in whicin capacity she cannot be surpassed. Wich her speed, breeding and manners she should make an exceptionally good brood mare. 


\section{No. 13 ELLEN WINTER}

Trotter. Bay mare. Foaled 1908. Standard and Registered. Bred by A. T. Cole Wheaton, Ill. Consigned by Allie Robbins, Good Ifope, Ill. Consigned by Allie Robbins, Good Hope, Ill.

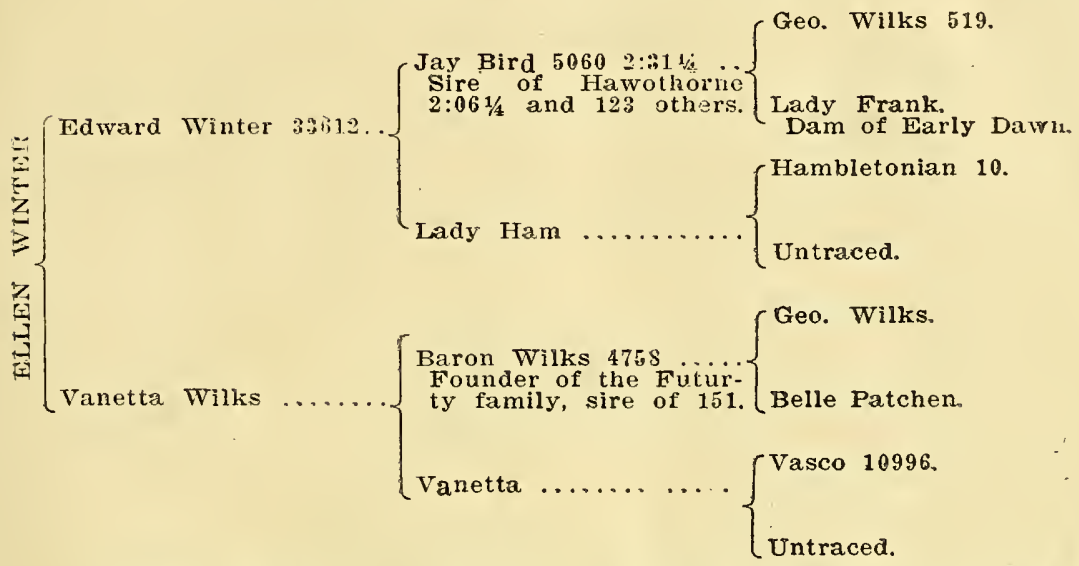

Owner's Statement--This mare could trot a half-mile track in 2:30 at three years old, and the iast eighth in $171 / 4$ seconds. She was not trained as a 4-year-old, and is now big and strong. With her breeding, is certainly qualified for either a race or brood mare. 
H. E. Pennington

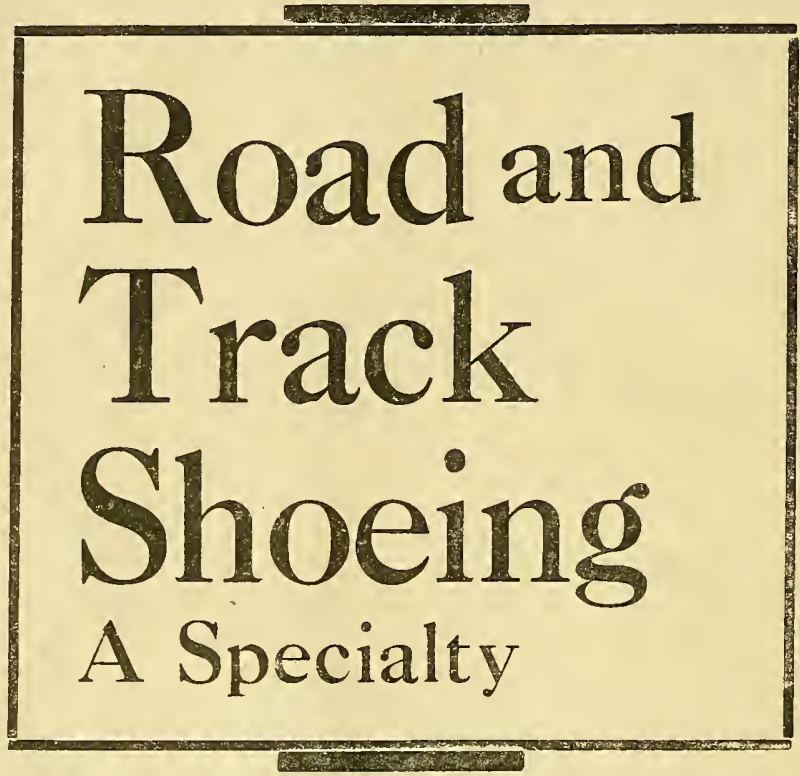

Special Attention Given to Lame, Interfering and Faulty Gaited Horses

130 S. Lafayette St. MACOMB, ILLINOIS 


\section{No. $14 / \%$ ROGEN EARLE}

Trotter. Chestnut mare. Foaled 1909. Standard and Registered. Bred by A. H. Wingate, Avon ,Ill. Consigned by Allie Robbins, Good Hope.

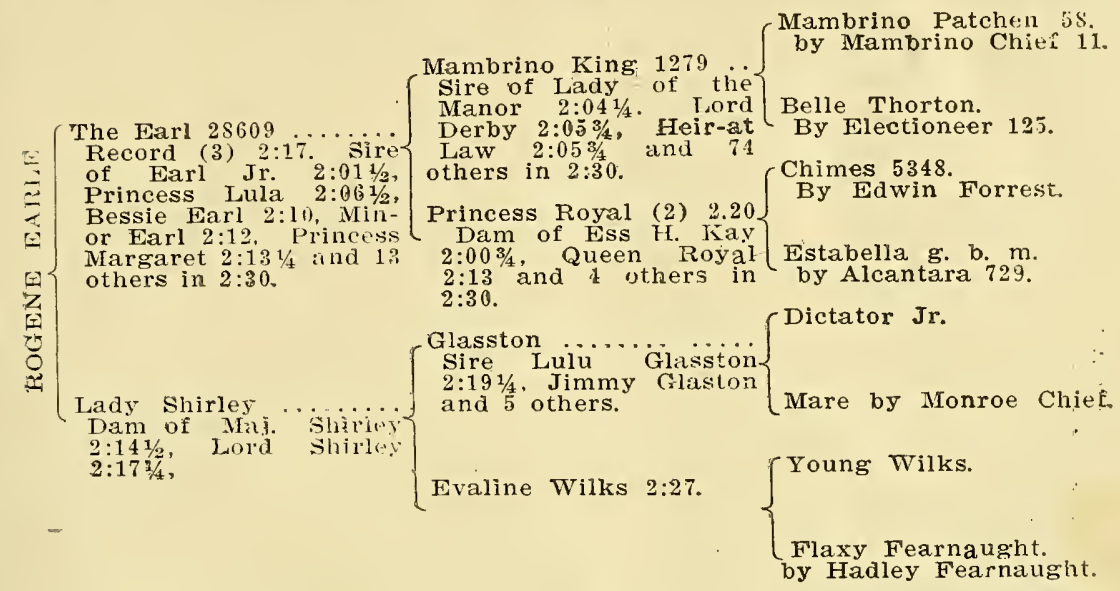

Owner's Statement-Rogene Earl is a large, strong-going filly, and with ninety days' training, including breaking, paced a mile over tha Macomb track in $2: 34$; last eishth in 17 seconds. She is a half-sister to Major Shirley 2:14 1/4, and Lorl Shirley 2:17 1/4. She looks like the making of a fast mare. 


\section{Dam of Signal Boy 2:1414.}

Dignal Boy was one of the best trotters out last season and sold for $\$ 2500$. Trotter. Bay mare. Registered. Consigned by Allie Robbins, Good Hope, III.

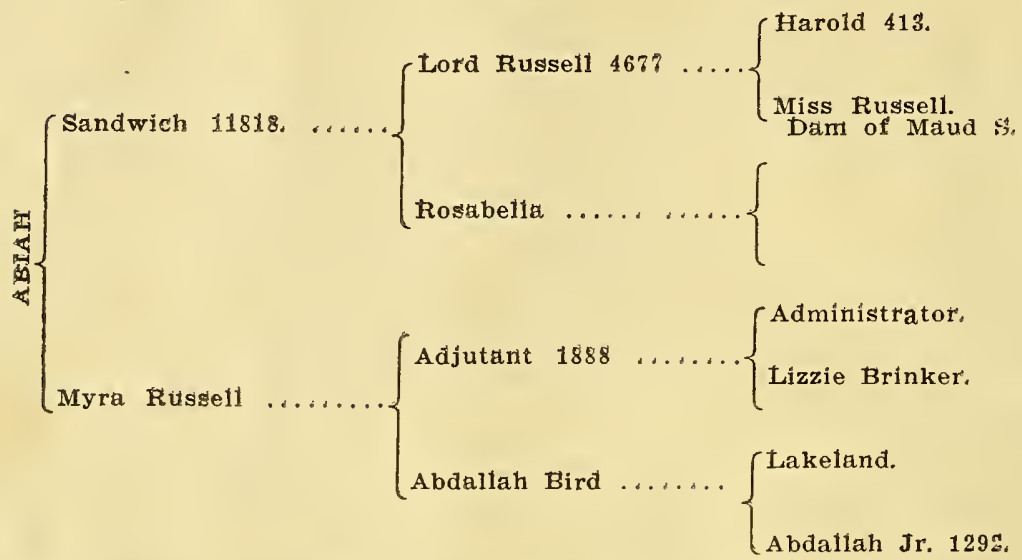

Owher's Statement-Abiah, the dam of Signal Boy $2: 141 / 4$, is a mare of extra quaiity and action she has never been trained but is a pure gaited trotter. In the last eight years she has produced eight foals. If given the right kind of a chance will surely produce more very usefui trotters. She is now bred to Cignette $2: 20 \frac{1}{4}$, the sire of Signal Boy 3:14:1/4. 


\section{No. 16 PATRICA WIGGINS}

Trotter. Bay mare. Foaled 1910. Standard and Registered. Consigned Allie Robbins, Good Hope, Illinois.

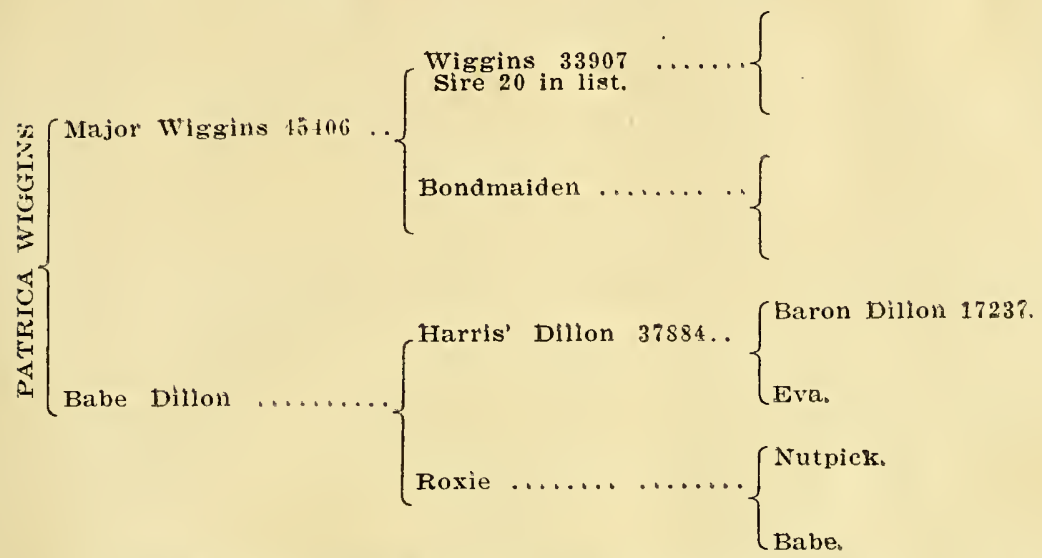

Owner's Statement-Patricia Wiggins was trained lightly last year as a two year old and learned to trot an eighth in 21 seconds quito handily. She will make a good sized mare with plenty of quality and the best of feet and legs. 


\section{No. $17 / /$ ABBIE KING}

\section{Out of Dain of Signal Boy 2:1414.}

Trotter. Sorrel filly. Foaled 1912. Standard (sire and dam registered). Bred and Consigned by Allie Robbins, Good Hope, Ill.

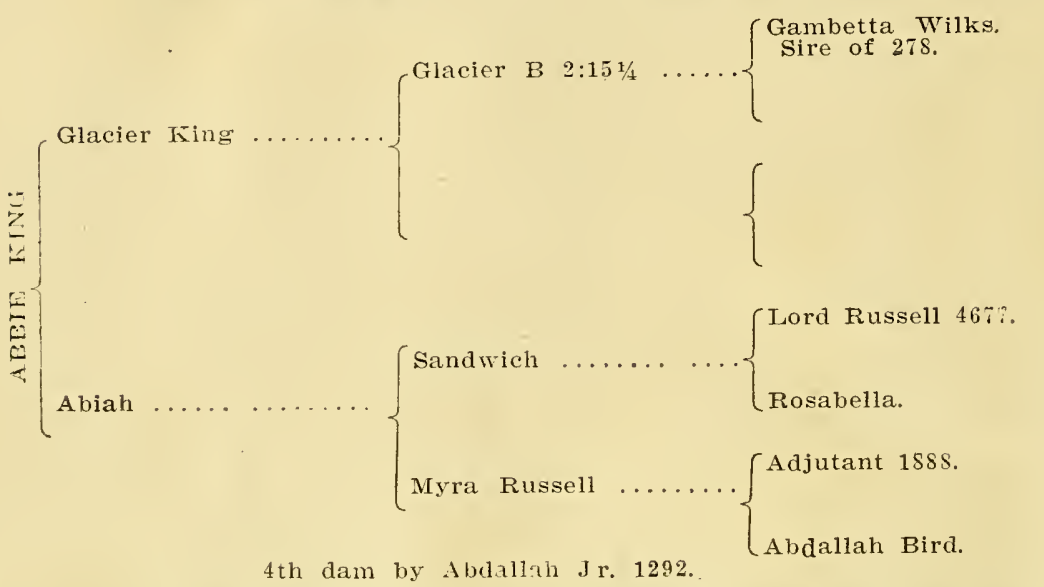

Owner Statement-This is a handsome bay filly with good growth and snap and acts like a trotter. She should be as good as her half brother, who was one of the best trotters out last year.

\section{No. 18}

\section{MISSOURI GIRL}

\section{Public Trial 2:1914.}

Pacer. Bay mare. Foaled 1906. Consigned by Allie Robbins, Good Hope, Illinois.

Owner's Statement-This is an extra nice mare in the harness, a good road mare; stands 15.2 and weighs 1000 1bs. She was worked last season and paced a 1/2 mile track in $2: 19 \frac{1}{4}$, last half in $1: 09$ and eighths in 16 seconds. She will make you like her. 


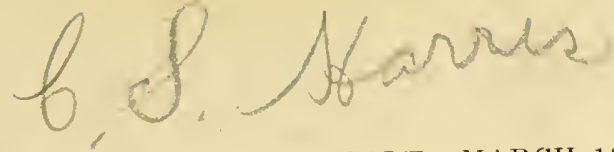

IVESTERN ILLANOIS HORSE SALE-MARCH 13, 1913.

\section{ROXE}

Worked in 2:40 With Three Days Handling.

\section{Worked His Third Nile in 2:30 With Eighth in 17 34. secouds.}

\section{Family of General Forrest 2:08.}

Trotter. Bay gelding. Four years old. Bred by J. B. Elliott, Knoxville, Iowa. Consigned by R. H. Rexroat, Macomb, Illinois.

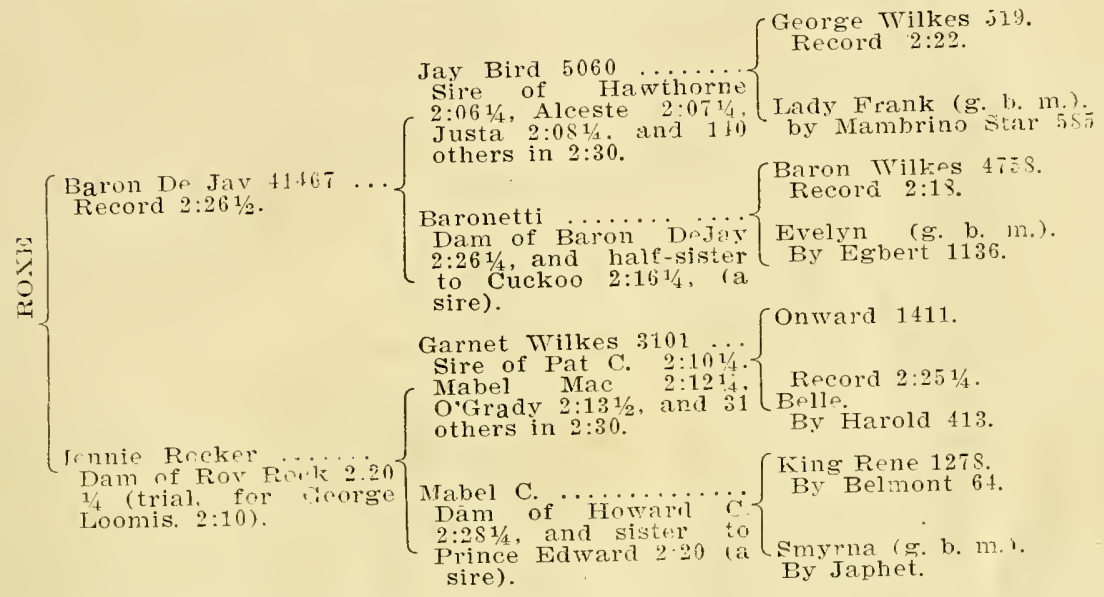

Garnet Wilkes 3101 sired the dams of Spill 2:061/2. Ingoldsbe $2: 11 \frac{1}{4}$, Jack 2:18. Ericca E. 2:15 1/4 Tom Ross 2:161/4, Little Boy $2: 13 \%$, Prairie King 2191/4 Willie Hamilton 2:19 1/4, Ada Garnet 2:201/4. Roy Rock 2:201/4, and 8 others in $2: 30$.

Owner's Statement-Roxe is a beautiful bright bay, kind and gentle in every respect, the best of stable manners and cold be used for a ladies driver. Is sound and one of the best racing procpects of the season. Last year, with three days work, after being put in the trainer's hands, he stepped a mile in $2: 40$, and with forty days training he worked his third mile in $2: 30$ and the last eighth in $173 / 4$ seconds. He was then withdrawn from training to be saved for this year. He is four years old and in condition to be put in active training and will make a winner in the races this season if given a chance. The owner has three two-year-olds which he wishes to develop and they require all the time he can spare from his business. The buyer of Roxe can rest assured that he owns ? horse that will make good either as a race, matinee or fun horse. Too many horses is my reasnn for sel'ing

If you are a member of the Driving Club you can get a winner in this vatalogue. 

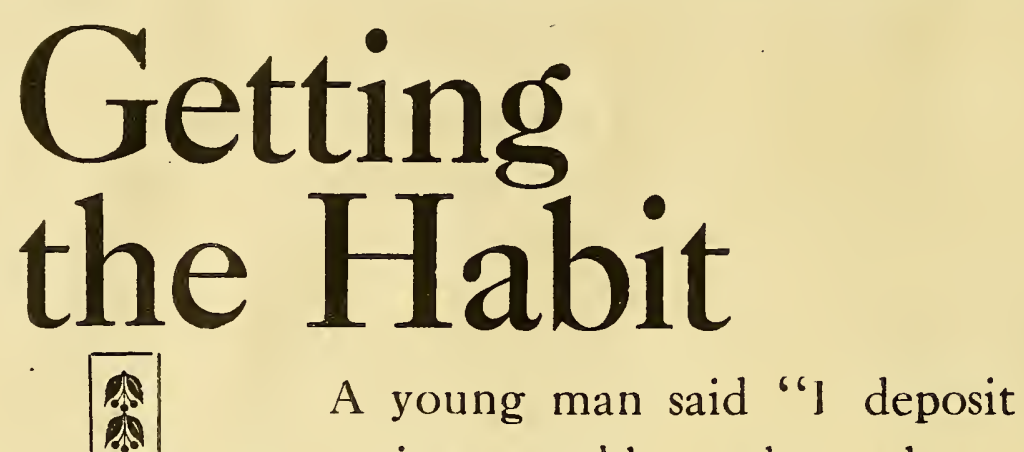
my savings weekly rather $\mathrm{th}$ a $\mathrm{n}$ monthly, because the oftener I make the deposit makes the savings habit that much stronger.

You become not only a confirmed money save, but a real investor, one who, even in small matters, places safety hrst.

Wouldn't it pay you to establish the habit of investing in a savings account at the

\section{First Trust \& Savings Bank of Macomb}

\section{DIRECTORS}

R. S. Blackstone Ross Miller
C. W. Fiack

T. M. McFudden

f M. Pelley
A. A. Messmore Frank Haynes 


\section{No. $20 \%$ FRANCES M.}

\section{Sister to Jay Nedium 2:28 and Frances Red 2:2914.}

Trotter. Bay filly. Foaled June 10, 1910. Bred by J. L. Gilmer, Villa (Yrove, Ill. Standard (sire and dam registered). Consigned by

R. H. Rexroat, Macomb, In.

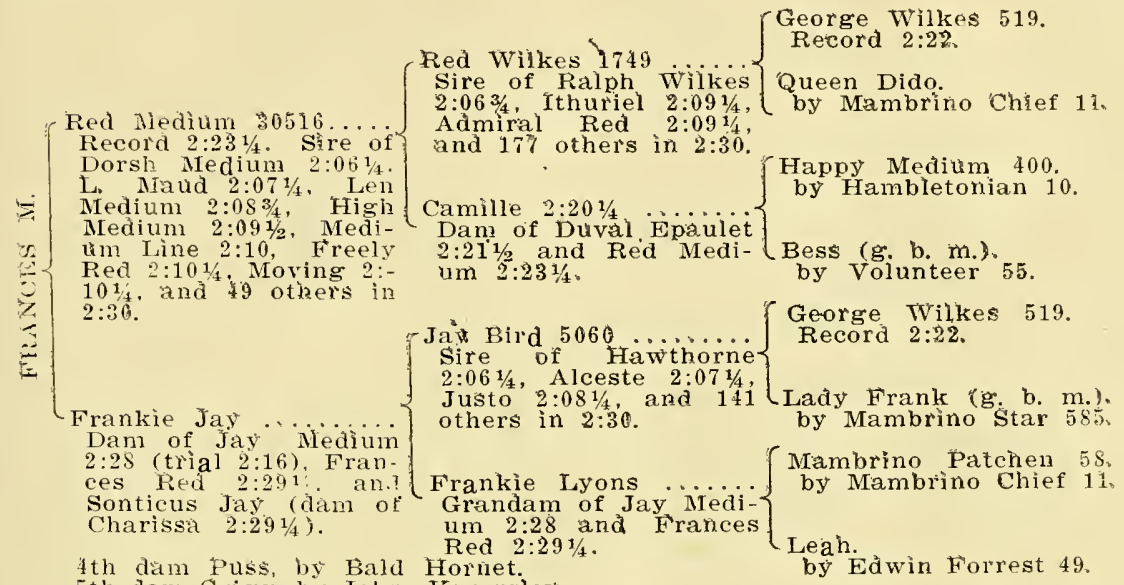

5 th dam Grieg, by John Knowsley.

Iay Bird so60, record (3) $2: 31 \frac{3}{4}$, sired the dams of Don N. 2:07 $\frac{1}{2}$, Barcness Virginia (3) 2:08 1/4 , Crescent Route 2:083/4, Bessie Drake $2: 083 / 4$, Codero $2: 09 \frac{1}{4}$, Codero $2: 093 / 4$, Altoka $2: 101 / 2$, Rebecca G. $2: 11 \frac{1}{4}$, Alice Edgar $2: 12 \frac{1}{4}$, Pretty Polly $2: 121 / 4$, Queen Alfred $2: 2$ $12 \frac{1}{2}$, Jessie Benyon 2:12 3/4, Litt'e Doc $2: 12 \%$, Baroness Evelyn (3) $2: 123 / 4$, and 89 others in $2: 30$.

Orner's Statement-Frances M. is a high-class filly; is well broken to harness, but has never been trained. She is improving nicely and shouid learn to trot fast. 


\section{Get Ready for \\ Spring Work}

Order your Work Harness made the way you want them.

The best assortment of Home-Made Harness in the county at

\section{D. Gumbart's}

Make up your list of the strap work and harness repairs you want and let us show you what we can do.

Sign of the White Horse
S. Side Square Macomb, Ill. 


\section{No.212 CORNER STONE}

Trial $2: 16$.

\section{Half in 1:0\% $1 / 2$; Eighth in 16 seconds.}

\section{Brother to Nordua $2: 225$. Pure bred Stallion No. A 8246.}

Pacer. Bay horses, 16 hands. Foaled 1904. Bred by Grassland Farms Indianapolis. Ind. Standard ard registered. Consigned by

Chandier Bros., Macomb, Ill.

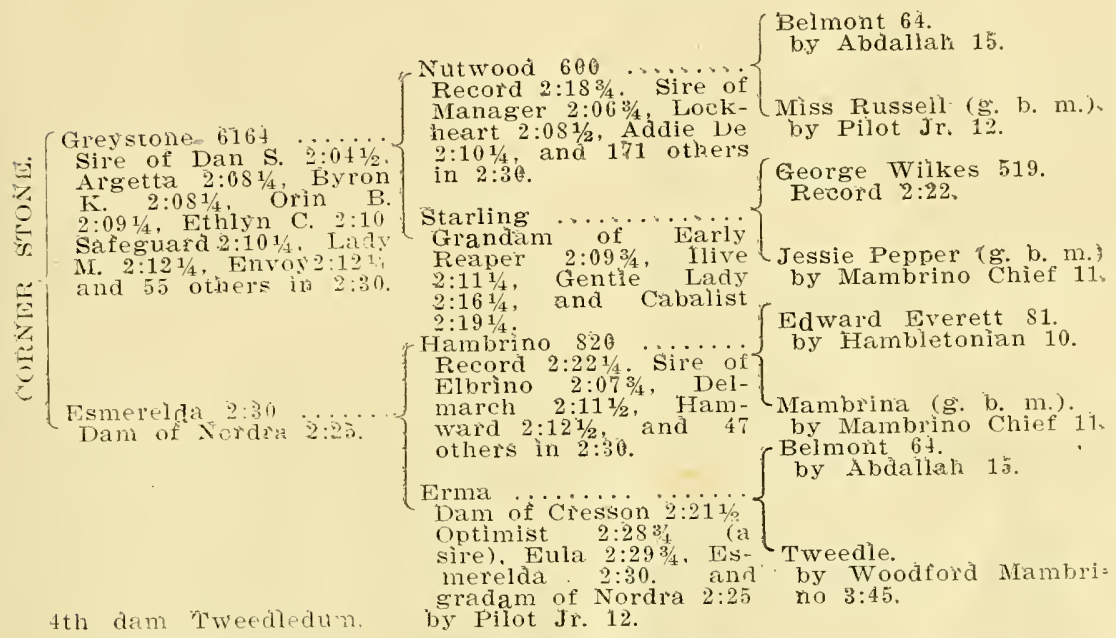

Ormers' Statement-Corner Stone has plenty of speed. His blood lines cannot be improved on. He has the Greystone-Mambrino cross that produced three horses with marks better than 2:10. Putherford Bros. of Austin, Minn., credit him with working a mile in $2: 16$. He won the matinee race here last summer; fastest half in 1:09. I have driven him a half in $1: 07 \frac{1}{2}$ and an eightr. in $1 \hat{h}$ seconds. He is a beautiful blood bay 16.1 hands high and weighs about 1200 pounds. No better dispositioned horse ever lived, either in or out of the barn. He does not care for autos or steam cars. He has plenty of mares here that show he is a foal getter. If rou wanc a horse that will pay himself out and make you good hard cash, one that you can have fun with and beat the other fellow, buy him. 


\section{No. 22 McDONOUGH COUNTY BOY}

Trotter. Black gelding. Foaĩed 1906. Consigned by Chandler Bros.,

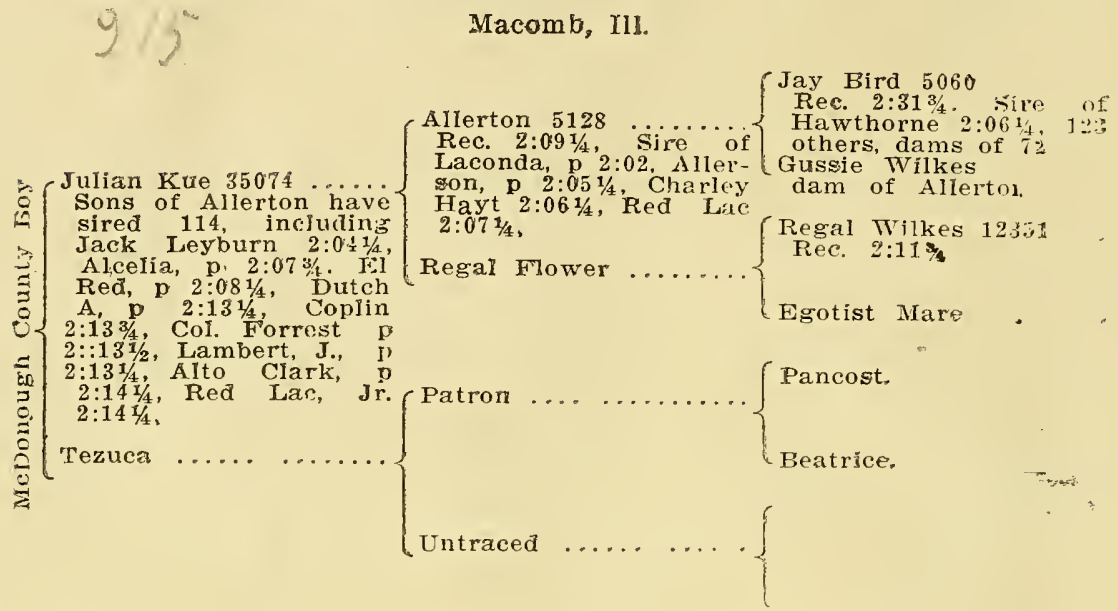

Tezuca was purchased in Missouri by TV. C. Sutton and was said to be standard. She showed good breeding, and an effort was made to trace her breeding, but it could not be accurately established; but she was a high breă mare.

Owner's Statement-Herc is the horse that will fulfill any picture in regard to beaty and intelligence. He is a coal black with two white hind feet; a beautiful, cresty, full-made neck that grows straight out of his wethers, topped off with a nice, clean-cut, well-proportioned head with a pointed, upheld, fox-like ear; a nice, full-made loin and back, with hips as smooth and rounding as an apple. He is used to city signts, drives on either a tight or loose line, has lots of action, and can brush a fair gait. If you are looking for a driver, look him over.

\section{Nos. 23, 24, 25 Reserved}




\section{No. $26 \quad$ RASTUS R. 51785}

Trotter. Black colt. Foaled 1909. Standard and registered. Bred and consigned by James Runkle, Macomb, Ill.

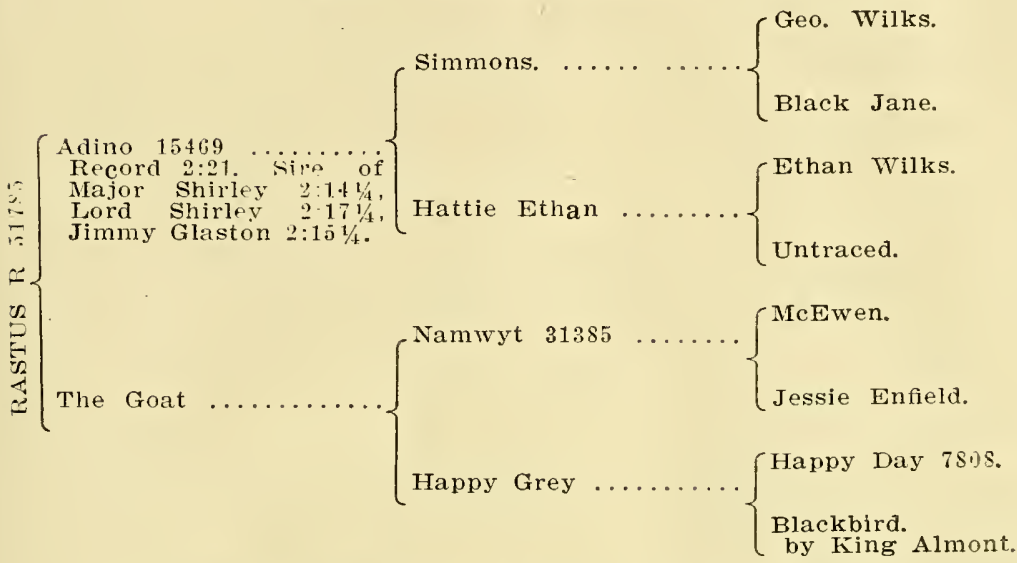

Owner's Statement-Here is a fine looking colt which has never been handled for spees. but from his rreeding he should be able tu stell fast. Witil work he will doubtless show fast. $\mathrm{He}$ is well broke and kind to hancle. He is a good prospect and will make a good stock horse.

\section{No. $27 /$ DAN PATCH 2d}

Trotter. Bay gelding. Foaled 1908. Standard (sire and dam registered)

Bred by Harve Helms, Bushnell, consigned by Harry Rich, Bushnell.

Owner's Statement-This is a large handsome fellow, resembiins Dan Patch in size, color and conformation standing 16 hands or better. He is a toppy hitcher and a show horse in gait and possessed of considezable speed but it is all natural as he was never trained. 
Roark Sells the

Best

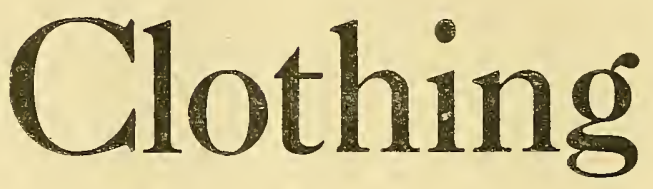

Hats and Furnishings

128 and $130 \mathrm{~N}$.

Macomb,

S. Square

Illinois

\section{DOUG TURNER'S}

Feed, Boarding and Sale Stable

TURNER BROS., Props.

S. W. CORNER SQ. 


\section{No. 28 BESSIE PATCHEN}

Trotter. Black filly. Foaled 1912. Bred and consigned by Dan Darnaby, Macomb, Ill.

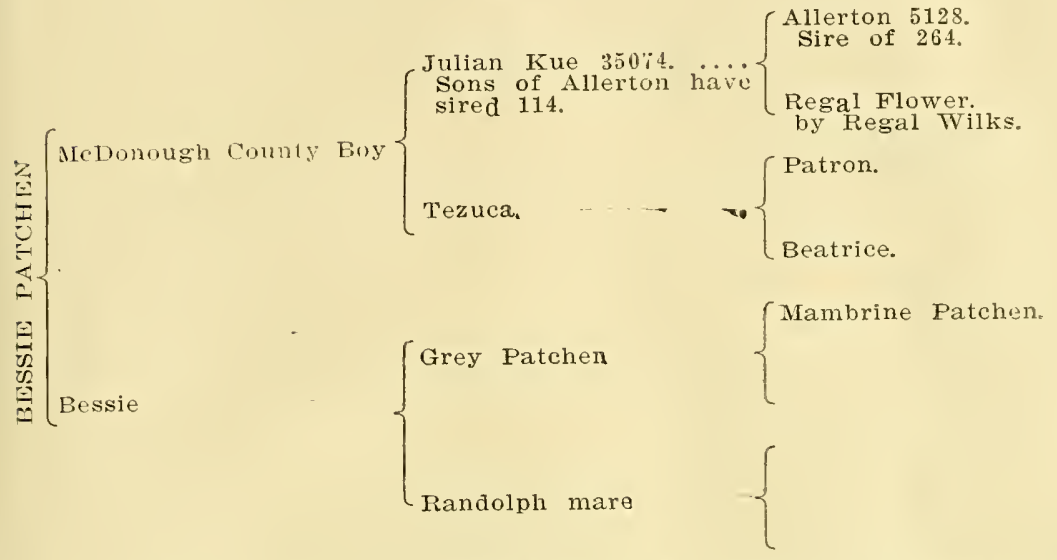

Owner"s Statement-Bessie Patchen is a nice, large filly and has shown good step in the lot. She has been harnessed but never hitched. She is in nice condition and will make someone a good mare.

If you are a member of the Driting club you can get a winner is this ratalogue. 


\section{No. 29 AARON RHOADES}

Trotter, Bay colt. Foaled 1911. Standard. Bred by John Calder Jr. Consigned by A. R. Baldwin, Keithsburg, Ill.

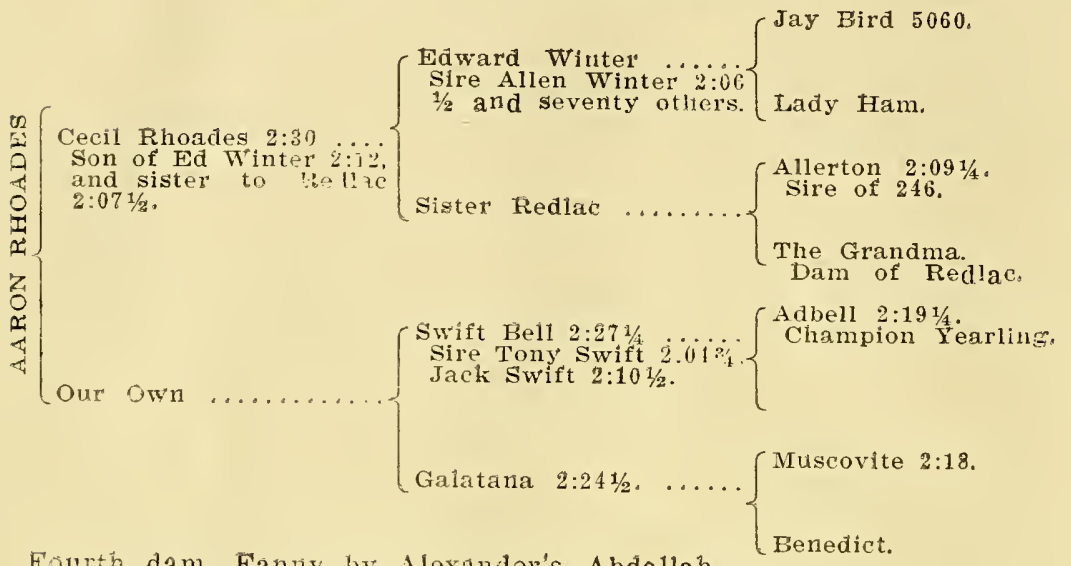

Fourth dam, Fanny by Alexander's Abdallah.

Owner's Statement-Is just mildly broken. Is a good looking, grand individual and sound.

\section{P. D. ROARK \\ Prescription Druggist \\ Exclusive Sale on \\ Rexall Remedies, Vinol and Sal Vet

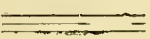

\section{North Side Square, Macomb, Ill.}




\section{No. 30 \& 5 CECIL ADVERTISER}

Trotter. Bay coit. Foaled 1911. Standard. Bred by Jôhn Calder Jr. Consigned by A. R. Baldwin, Keithsburg, Ill.

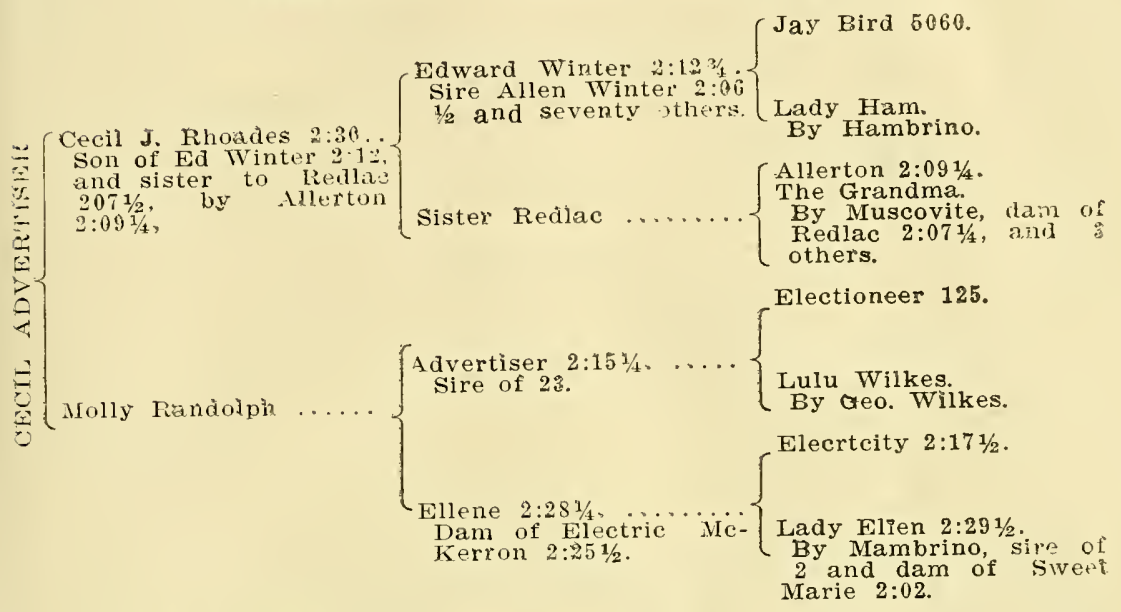

Owner"s Statement-This is a nice large colt. Ought to make a great trotter and a sire. Just nicely oroken but a grand, good gaited trotter. 


\section{No. 31 CECIL DIRECTUM}

Trotter. Bay colt. Foaled 1911. Standard. Bred by John Calder Jr.

Consigned by A. R. Baldwin, Keithsburg, Ill.

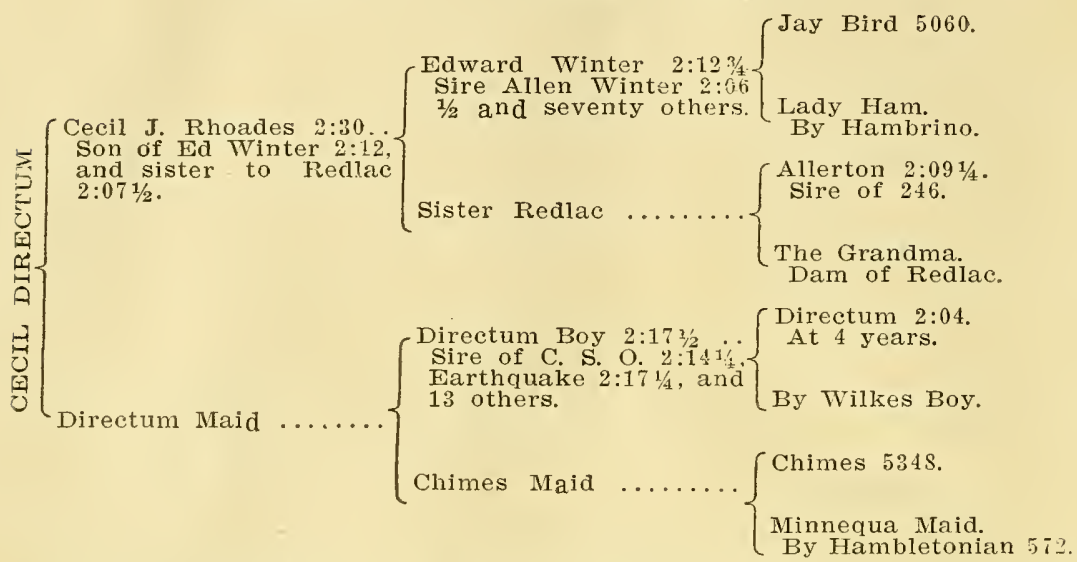

Fourth dam, Ida May Jr., lam of 1; by Owen Dale, sire of third dam of John A. McKerron 2:041/s, and dam of Electric McKerroll, 2:251/2.

Owner's Statement-This colt will make a gem for someone. $\mathrm{He}$ is nicely broken and is a grand trotting prospect. A good individual and sound. 


\section{No. 33}

\section{ROY DILLON}

Trotter. Bay colt. Foaled 1910. Consigned by O. D. Harris, Plymouth.

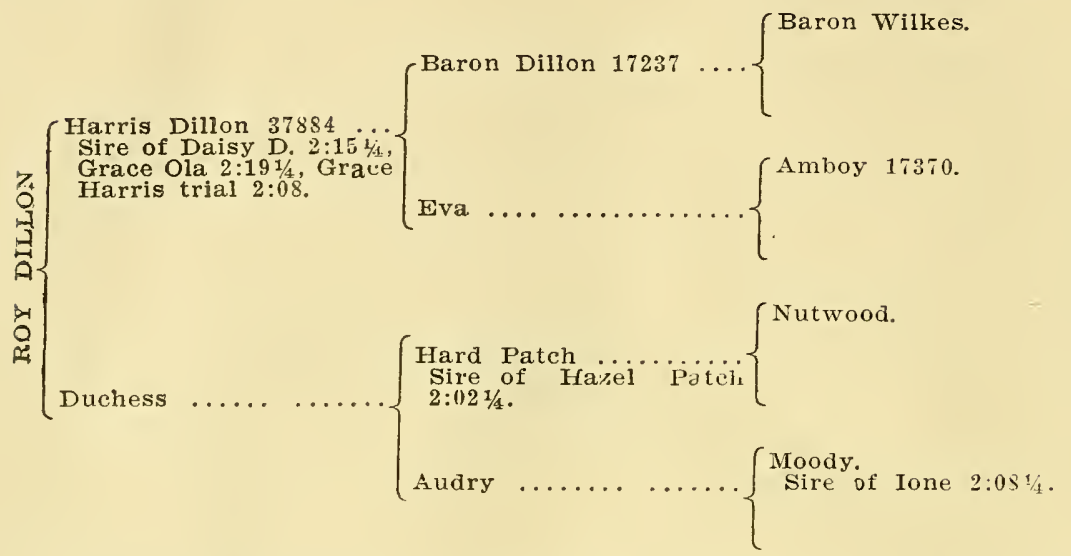

Owner's Statement-This colt is nicely broken and will show quite a lot of speed, although he has been handled but little and never tried out to see how fast he really is. He is bred high to make a race horse and is just the kind to buy for the driving club and deveiop him into something valuable.

If you are a member of the Driving Club you can get a winner in this catalogue. 


\section{No. 34 BUSTER THOMAS}

Trotter. Bay colt. Foaled 1911. Consigned by O. D. Harris, Agent, Plymouth, Ilinois.

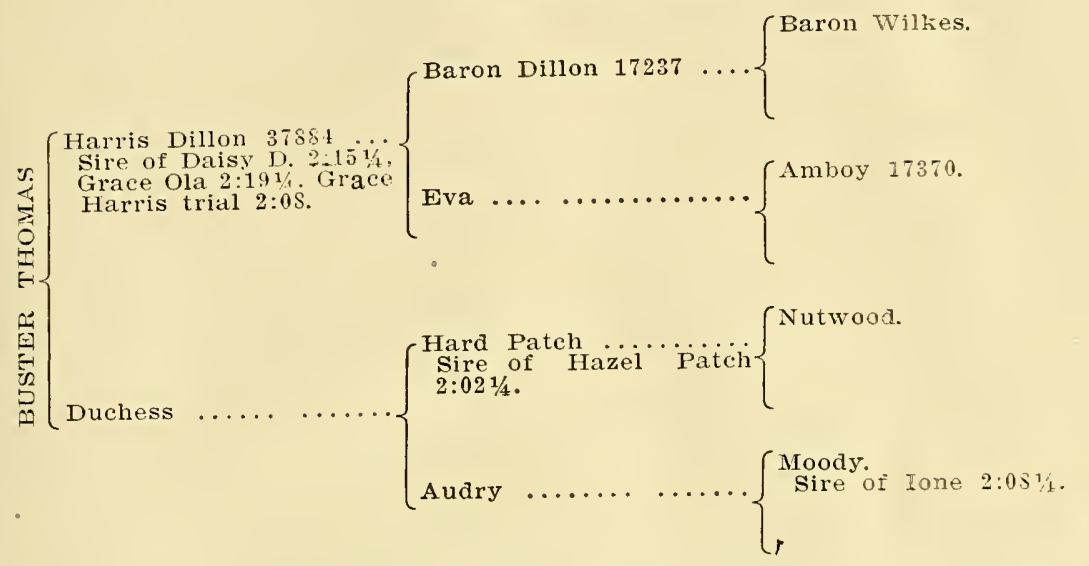

Ormer's Statement-This lellow is nicely broken and is a nice looking colt, a full brother to Roy Dillon, consequently bred right to make a gcod race horse. He has never been handled for speed but will show you that he is a good one when stepped up. 


\section{....See.... \\ Fellheimer's \\ New Spring \\ Stock of \\ Clothing and Gents' Furnishings}

North Side Square, Macomb, Ill.

\section{A. DOUGHERTY}

West Side Square

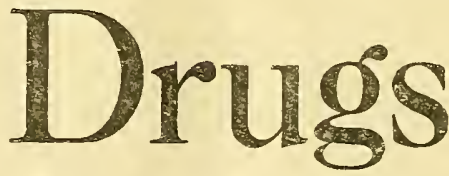

Elks

Building

When you want; what you want when you want it, come here.....

Gilkey's Veterinary Remedies.

Giles Veterinary Remedies.

Dougherty's Veterinary Worm Exterminator.

Phones Nos.........427 $\begin{gathered}\text { House } \\ \mathrm{R}\end{gathered} \quad 355 \quad 23$




\section{No. $3570 \quad$ PETE}

Pacer. Four years old. Consigned by A. R. Stickle, Macomb, Illinois.

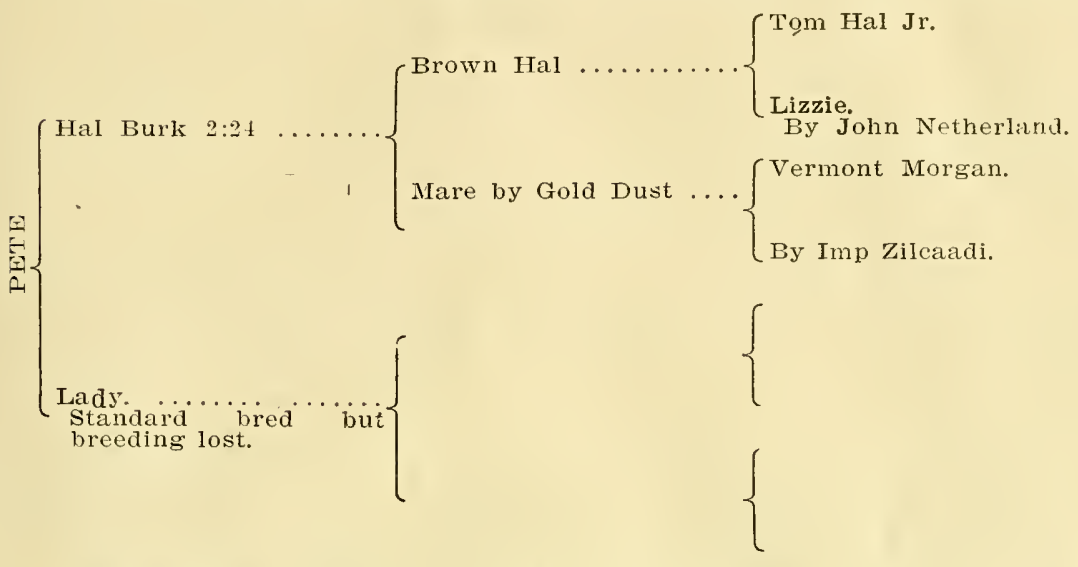

Owner's Statement- $\mathrm{He}$ is a trim little four-year-old ready for work. He has been hitched a few times and is bred to move fast. He is sure some pacer now with no handling for speed. 
No. 36

MAC

Frotter. Sorrel gelding. Foaled 1907. Consigned by A. R. Stickle Macomb, Illinois.

Sired by the White Arabian Stallion owned by Dave Thomas, of Swan Creek, Illinois.

Dam-A mare named Laily, Standard Bred.

Owner's Statement-He is a nice dark sorrel and is full of vim and go but is quiet to handle and a lady can drive him. He is broken single and double and is a good saddle horse and broken to drive cattle. $\mathrm{He}$ is coming six years old.

\section{J. A. WEABER \& SON}

Try Us Once, It Pays

COMPLETE LINE

Spring Suits, Coats, Shirts

Underwear, and Hats

\section{Society Brand Clothes, Manhattan Shirts, Knap Felt Hats}

There are a good many colts here that will develop fast. 


\section{No. 37}

\section{NIG}

Sired by Edina, a great horse.

Dan-A roan mare, half Arabian.

Owner's Statement-Nig is a nice black and is a good double and single driver.

\section{No. $38 / 60$ GYP}

Combination Saddle and Driving Mare. Black Foaled 1903 . Consigned by Mrs. Addie Hendee, Macomb, Ill.

Owner's Statement-This mare has been used in our family as a family horse and is quiet and tractable in every way; is automobile broke and a pleasant driver. She is a fine saddle horse. Is sold only because I do not need ser.

Nos. 39, 40, 41, 42 RESERVED

\section{SATISF A CTION}

When you go in for anything you no doubt want the best to be had. There is dependence to be placed on every article we recommend to you and satisfaction is certain if you use them. We give you absolute values at lowest prices.

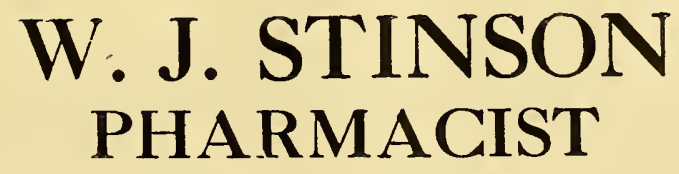

Both Phones 268

WEST SIDE SQ.

MACOMB, ILL. 


\section{J.

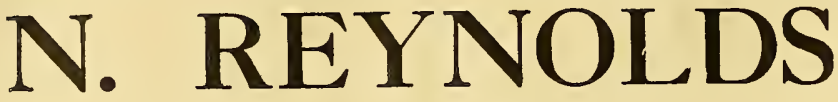 \\ DRUG STORE}

S. E. Corner Square,

Macomb, Illinois

Send all your Drug orders to us and you will be pleased with every purchase. There is a personal guarantee which goes with every article we sell. Our rule to dispense the best went into effect the day we started in business. No better can be had anywhere at any price.

\section{Union Cafe}

\section{Meals, Lunch and Short Orders}

OYSTERS SERVED ANY STYLE

The Best Coffee on Earth

Tom A. Adcock, Prop. East Side Squars 


\section{Consignment of Geo. E. Luster, Jr.}

\section{ANNOUNCEMENT.}

The stock offered for sale in this catalogue is owned by Geo. E. Lusw ter Jr. We guarante each and every animal is bred as lepresented and the title good. We think them sound but you must be yonr own judge. We do not guarantee sonudness. As you will see this bunch of colts are entirely undevcloped and in the rough. The trotting horse yame as you know at the best is a lnttery. Where you consider the suprely breeding of this stock is it not possible, yes probable there may be 2:10 trotters and pacers in this bunch. Here is a chance for some horseman to reap the benefit of development. We raise them for that purpose.

Respectfully Submitted

G. E. LUSTER JR.

\section{FUR REFERENCE ONLY}

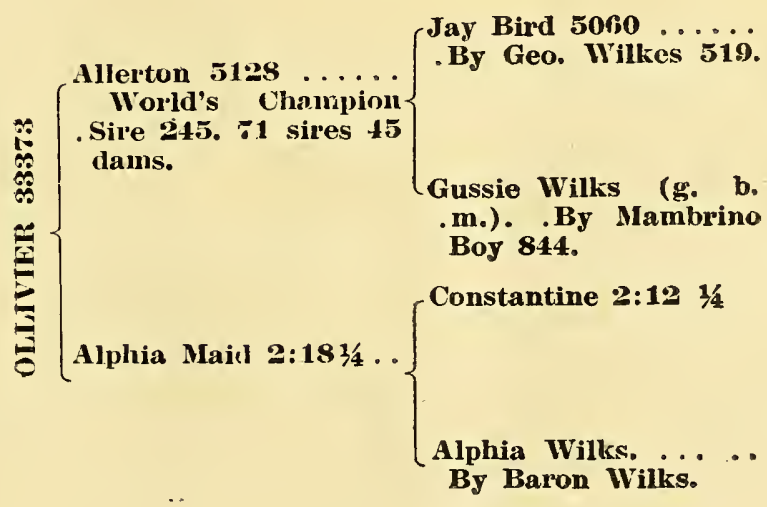

All the siores arlicitised in this catalogue are good places to trade. 


\section{No. 43}

\section{HELEN}

Trotter. Bay Filly. Foaled April 1910. Bred and Cousigned by the Luster Stock Farm, Good Hope, Ill.

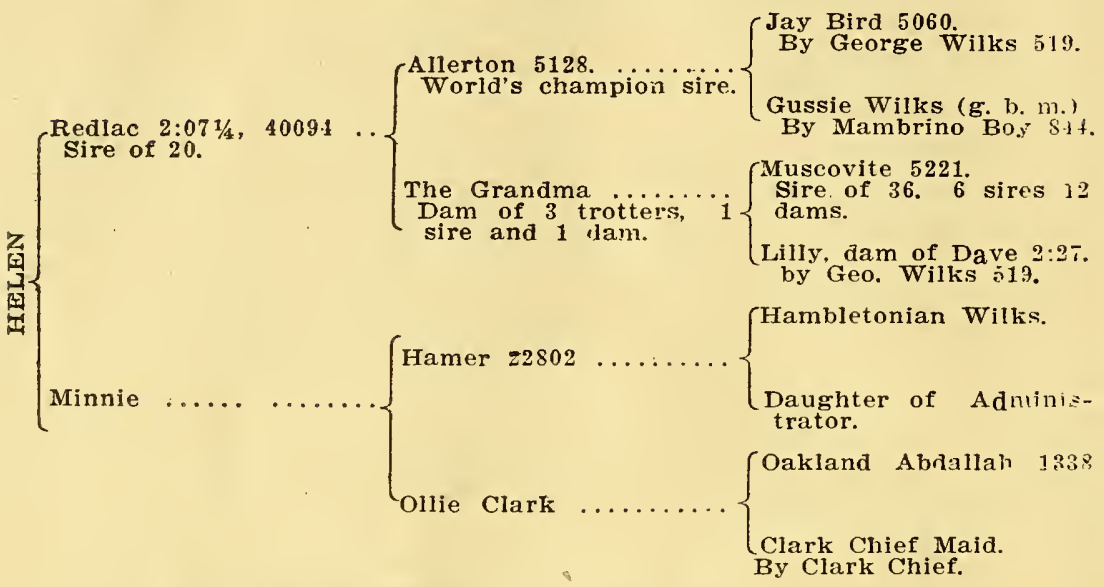

4th dam by Robert Lee, 5th dam by Blinker Deen.

Owner's Statement-A well bred filly halter broke only. Should be fast corsidering breeding and uam. Consider well the breeding of this filly by the fastest son of the noted Allerton. Redlac himself a great sire then notice the $\Pi$ ilkes and Hambletonian crosses, last but not least the noted Clark Chief blood, he being the sire of Kentucky Prince. The sire as you know of the dam of Axworthy one of the greatest living sires today. If breeding will not produce speed it is useless to try farther. I might call your attention also to the Abdallah blood as you know traces airectly to Maud S. This mare was taken out of pasture four weeks ago. Here is a diamond in the rougin. Oakland Abdallah was by Lakeland full brother of Harold sire of Maud S. 


\section{No. $44 \quad$ RED STAR}

Trotter. Bay Gelding. Foaled June 5, 1910. Bred and Consigned by Luster Stock Farm, Good Hope, Ill.

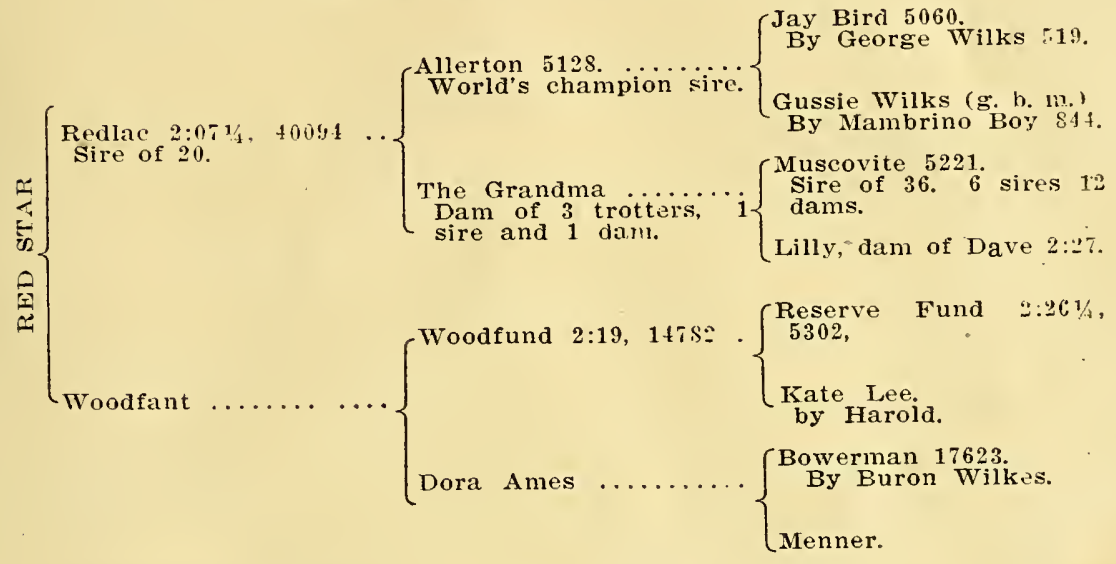

4th dam Minnie Banker, by Banker Messenger, 5th dam Morgan Mare by by Justins Morgan.

Owner's Statement-Halter broke, taken out of pasture four weeks ago. Another extra well bred Redlar. Notice the dams, the sire of the 1st dam a fast horse, this should be a valuable colt. Reserve Fund's Dam, Kate Lee, dam of Woodford $2: 193 / 4$, Colonel Mon 2:23 by Harold. 


\section{No. 45 ELMER MUSCOVITE}

Trotter. Bay horse. Foaied June 4,1908. Bred and Consigned by the Luster Stock Farm, Good Hope, IIl.

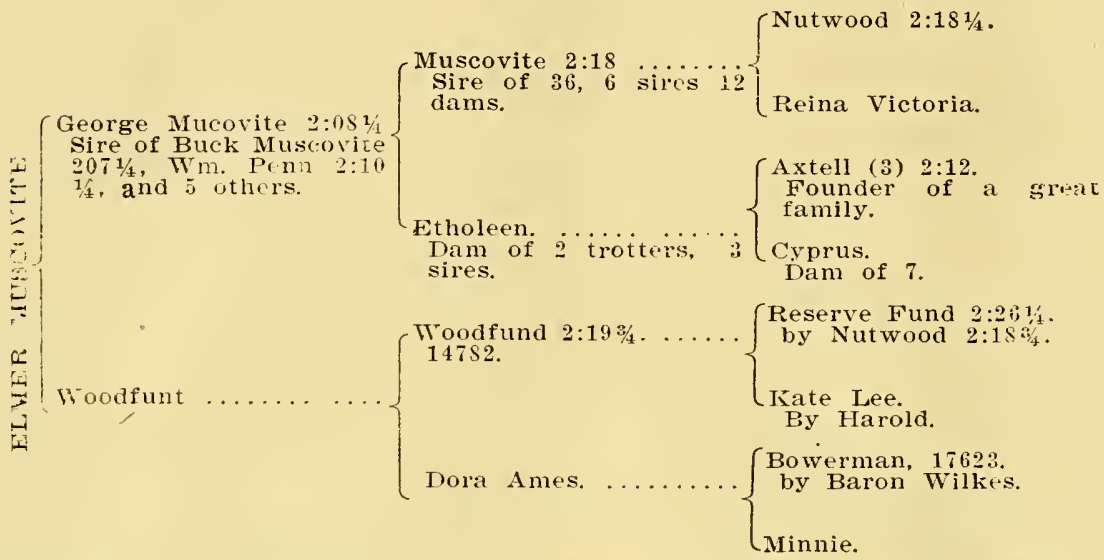

4tli dam Minnie Banker by Banktr Messenger, 5th day Morgan Mare by Justins Morgan.

Owner's Statement-This gelding is simply halter broke according to breeding should be valuable. 


\section{No. 46}

\section{BESSIE MUSCOVITE}

Sorrel niare. Foaled May 19, 1905. Bred and Consigned by The Luster Stock Farm, Good Hope, Ill.

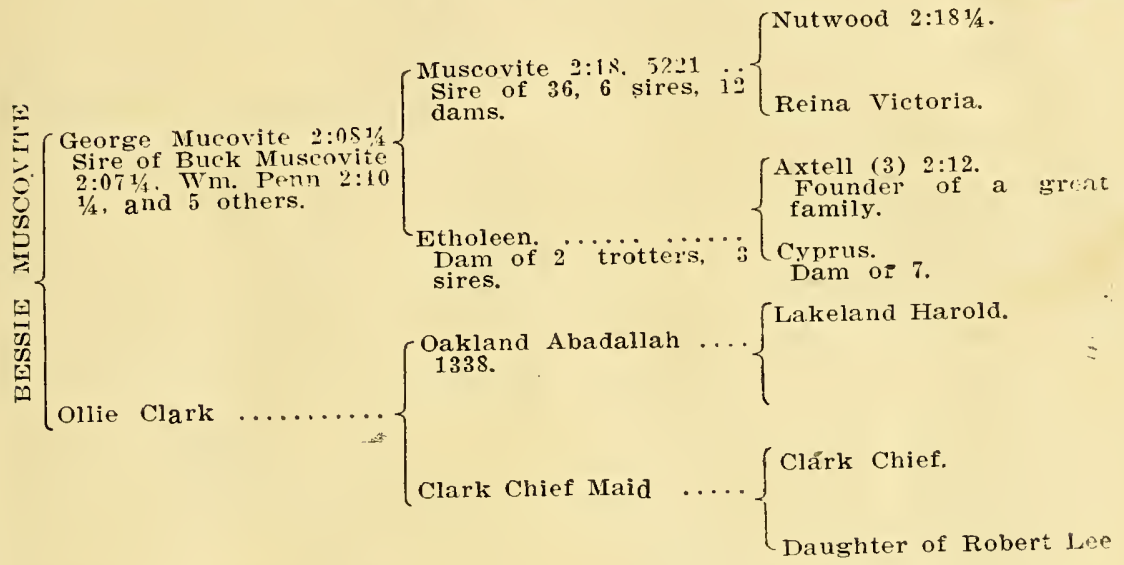

4th dam by Blinker Deen.

Owner's Statement-Lired July 7, to Aleuxenite 5323 in foa? to Aleuxenite. I belieze the best lired son of Allerton. Aleirimite Ist dim Euxnite race record 2:11.1, trotting Euxnite by Expedicion by Electioneer etc. Euxenite first dam, Euxine by Axtell 2:14 1/4, Euxine the dam of Euxenite 2:141/4, trotting, Libbie Queen 2:15 trotting. Guy John very fast record around 2:15 and one or two others. Euxenite 2nd dam. Russia by Harold Euxenite, 3rd dam Miss Russell by Pilot Jr. Euxnite, 4th dam Boston, noted thorough bred. Can you beat the pedigree of this foal? Combining three crosses close up of the noted Miss Russell, Expedition's 1st dam having a cross. Euxnite's 3rd dam Miss Russell. Euxenite's 2nd cam, a full sister of Maud S., then the Miss Russell cross again by Nutwoorl consider the fact that Miss Russell today stands at the head of the ist as a producer of 2:10 speed. I repeat can you conceive of a colt having a more fashionable ored pedigree combining the blond of Nutwr nd. Pilot Jr. Axtell, Expenition Harcld Clark, Chief, Allerton. Volunteer, American Star,last bui not least the Boston thorough bred cross and others to numerous to mention. Study the pedigree for yourself. 
No. 47

JOE

Trotter. Bay Colt. Foaled April 13, 1910. Bred and Consigned by The Luster Stock Farm, Good Hope, Ill.

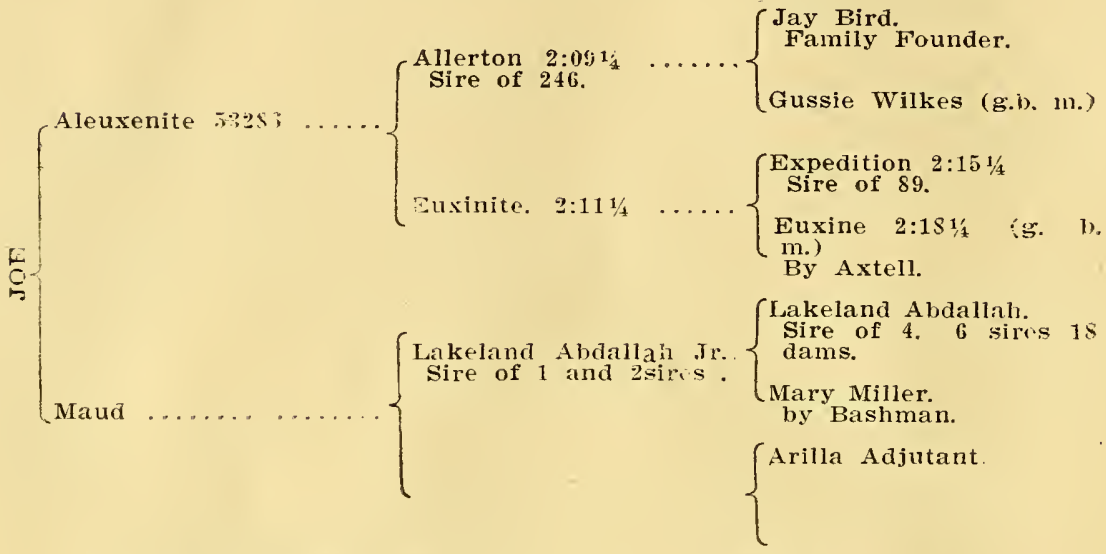

Owner's Statement-See foot note after Bessie Muscovite for Aleuxnite breeding. A well bred colt, simply halter broke.

\section{Joe Larner \\ Practical Horse Shoer}

\section{Specialty of Balancing and Cor- recting Faulty Gaited, Harness and Speed Horses.}




\section{No. 48}

\section{EDITH}

Trotter. Bay mare. Foaled May 24, 1907. Bred and Consimed by

Luster Stock Farm, Good Hope, Illinois.

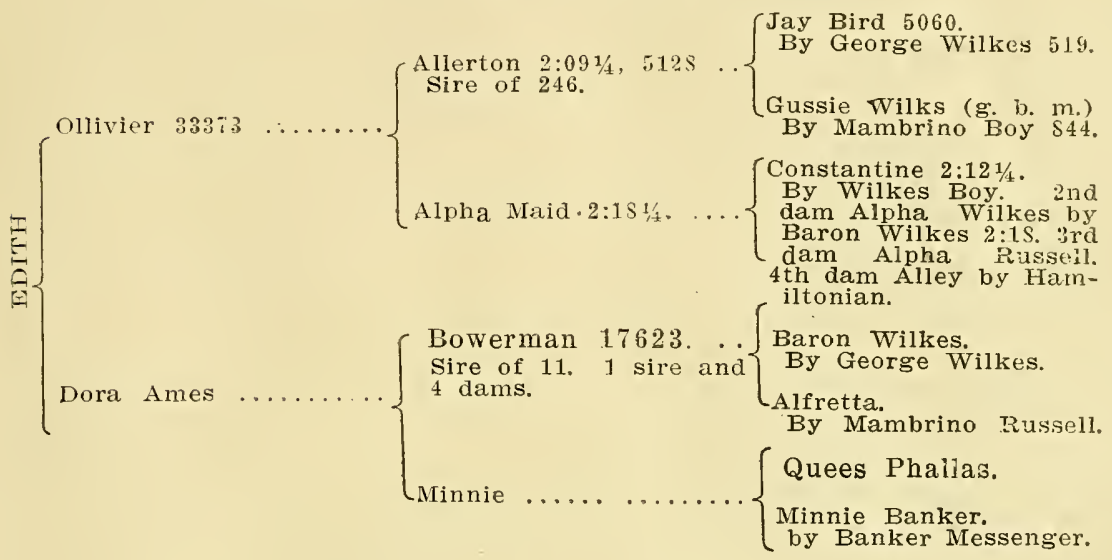

4th dam Morgan Mare by Justins Morgan.

Owner's Statement-Is halter broke. A well bred mare. I think should be good for bresding purposes or track. See Ollivier's breeding at head of consignment. 


\section{No. 49}

\section{GUY}

Bay Colt. Foaled June 1, 1912. Bred and Consigned by the Luster Stock Farm, Good Hope, Ill.

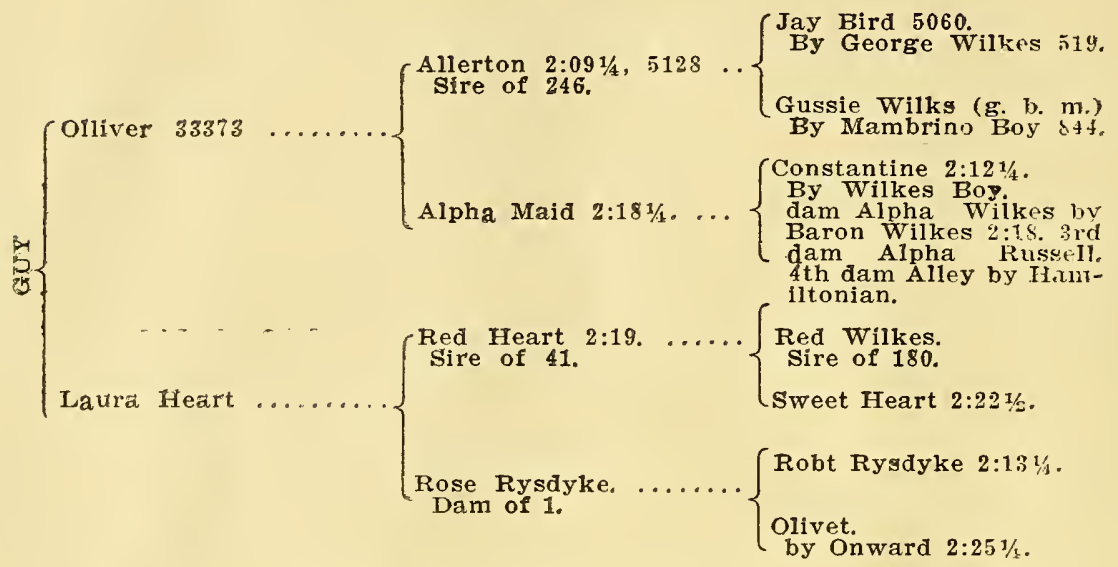

4th dam Santa Claus by Magic, 5th dam Josie Railey by Gen. G. If. Thomas.

Owner's Statement-See Ollivier's complete breeding in catalogue. A well bred colt. 


\section{No. 50}

\section{JUNE}

Bay Filly. Foaled May 17, 1912. Bred and consigned by the Luster Stock Farm, Good Hope, Ill.
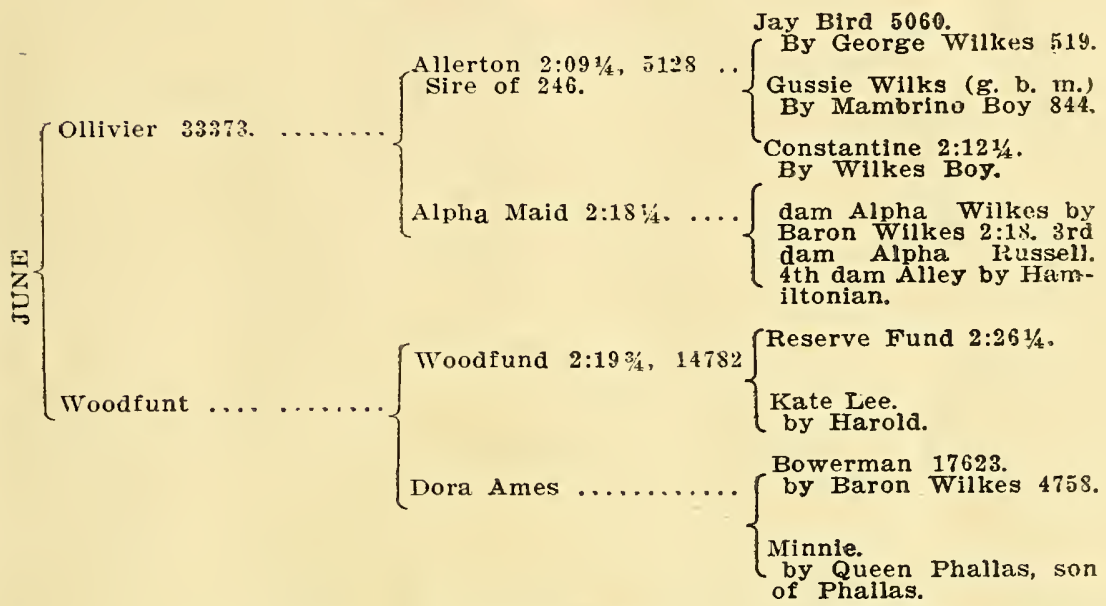

4th dam Minnie Banker by Kanker Messenger, 5th day Morgan Mare by Justin's Morgan.

Owner's Statement-Should be valuable either for breeding purposes or track. 


\section{No. 51}

\section{ERNEST}

Sorrel Colt. Foaled May 7, 1912. Bred and Consigned by the Luster Stock. Fiarm, Good Hope, I11.

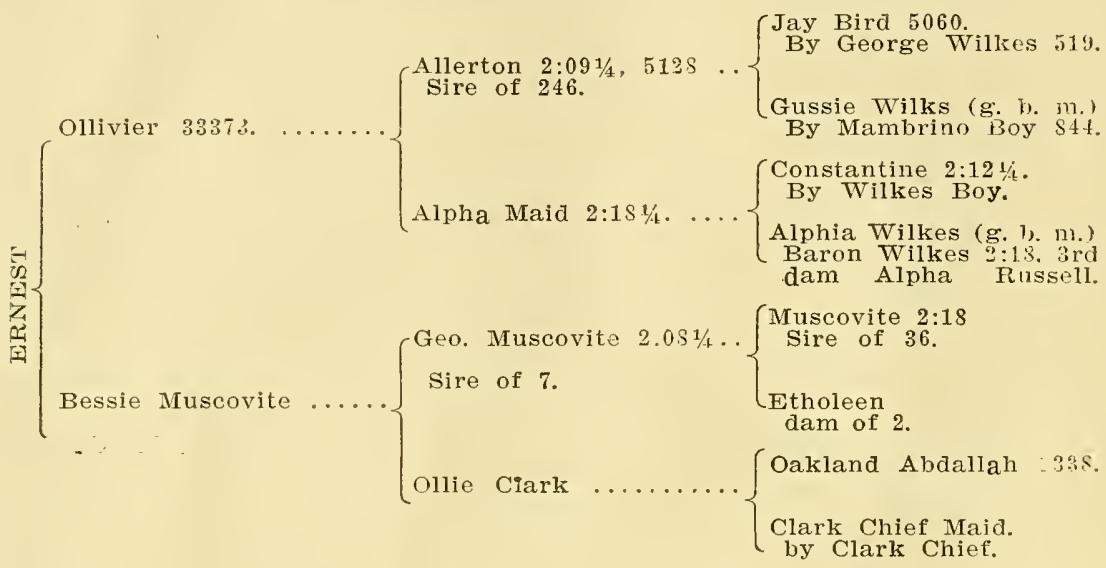

4th dam Robt. Lee, 5th dam Blicken Deen.

Owner's Statement-See catalogue for Ollivier's breeding, also Geo. Muscovite's breeding. This colt is simply halter broke, taken from pasture three weeks ago. If breeding counts for anything he should be fast. 


\section{No. 52}

\section{PEARL HEART}

Black Mare. Foaled April 20, 1908. Bred and Consigned by Luster Stock Farm, Good Hope, Ill.

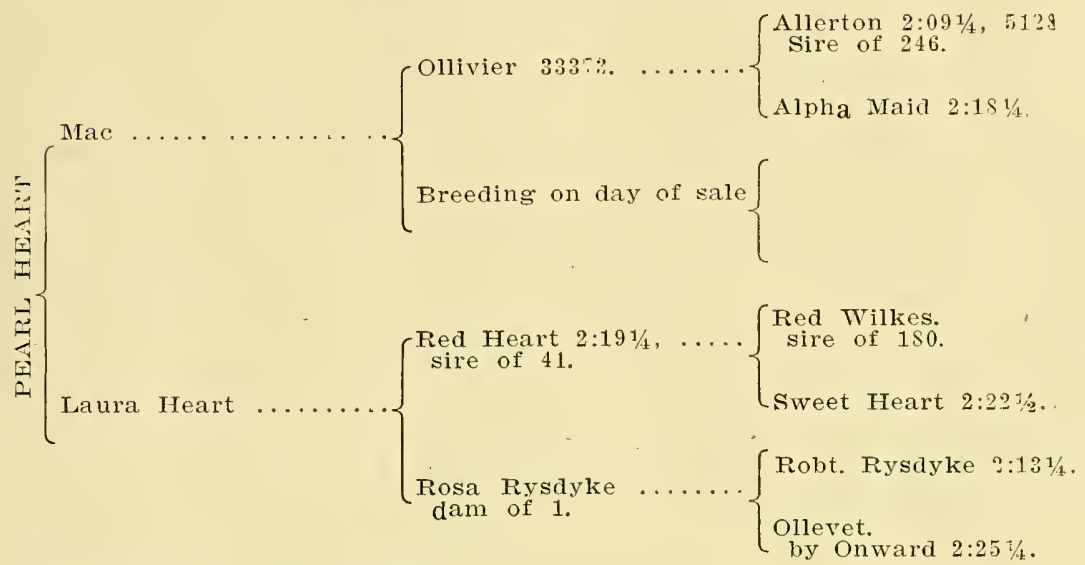

tundam Santa Claus by Magis,

Owner's Statement-You can notice, see in the catalogue Ollivier's breeding. This mare is simply halter broke but will step fast and make an elegant road mare. Her sire I am driving myself. Those who know the animal can inform you. 


\section{No. 53}

\section{DELMAS}

French Coach Stallion. Foaled 1904. C-No. 555 Grade. Consigned by

J. D. Tabler, Plymouth, Ill.

Owner's Statement-Very dark bay; black points; no white; weight 1400 pounds. His sire was imported and formerly owned at Huntsville. His dam is of French Coach breeding. I was informed by the breder of Delmas that he thought possibly that Delmas' dam was of full blood French Coach breeding. Delnıas is a beantiful horse of great strength and smooth build. Has proven himself a sure getter and sires fine specitrens for coach and all-purpose, and has always been a favorite with the putrons.

\section{Made One Big}

\section{Buy in SHOES}

Making the trip to Boston shoe market with eight other shoe buyers enabled us to buy any quanity that was offered.

We are offering Ladies' absolutely solid shoes in button or biucher in all 1913 styles for $\$ 1.48$. We also made a good buy in Men's and children's shoes which we are now throwing on sale for Spring bargains. So we are able to take care of you at prices that have never been offered you before.

"The Store That Makes Your Dollar Famous."

\section{A. T. STEWART \& CO.}

Who Sell Everything. 


\section{No. 54}

\section{MAY BUTTE}

\section{Registered in Vol XII.}

Consigned by Chandler Bros., Nacomb, Ill.

Dam of Burney 2:17 $\frac{14}{4}$; Grand dam of Nilma 2:05 34.

Sired by Tribute, he by Tribune.

Dam Madeline, by Tribune.

Owner's Statement-May Bute is a demonstrated brood mare; is the dam and grand dam of extreme speed. She is a mare of fine conformation, an easy keeper. The registration papers have been mislaid but will be on hands on date of sale. 


\section{No. 55}

\section{ALDA SHIRLEY}

\section{Race Record 2:15 3/4.}

\section{Trial 2:11. Half in 1:04.}

\section{Won three straight firsts. Was in the money 9 times out of 12 starts.}

Pacer. Chesnut sorrel niare. Foal ed 1907. Sonsigned by A. H. Wingate Avon, Ill.

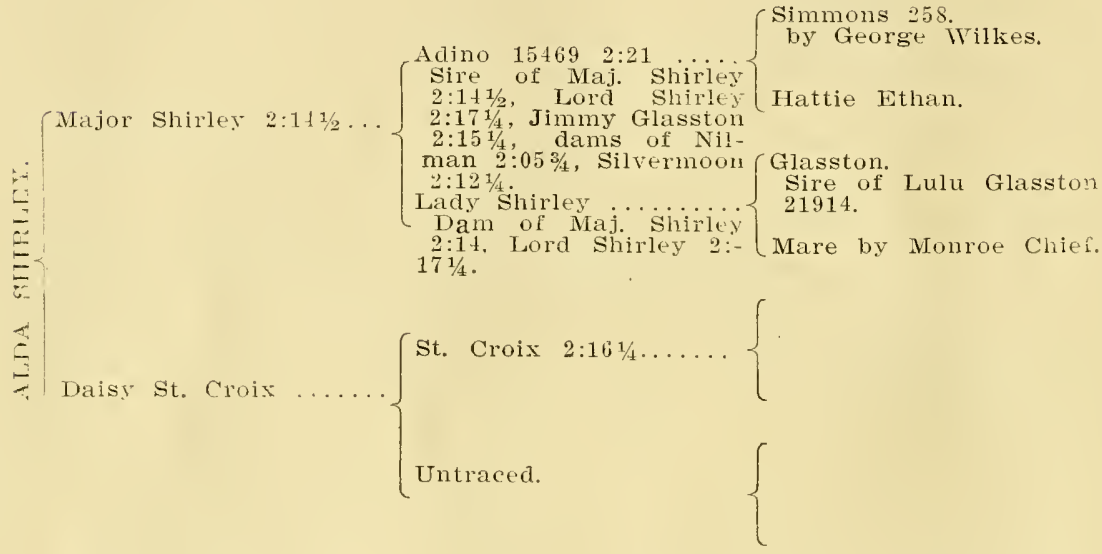

The second linu of this fast nare was brought to this state from California and proved to he an exceptionally fast road riare. When she showed so goos an effort was made to tracs her breeding "s le looks showed her to be high bred but the effolt was musncessful.

Ownel"s Statement-Aida Shirley is a beautiful sorrel chestnut mare, and was a good, consislent race mare last season, winning three straignt races in two weeks. She not only won three firsts but was in the money nine times out of twelve starts. Today she is as sound as a new-milled collar. She las been a half in 1:04 and a mile in 2:11. She is not near the end of her speed by any means; is easy to drive, and will make an ileal race or matinee mare. Where could you beat her for a fun mare to beat your friends? 


\section{A. T. EWING \& SON}

DEALERS IN

Best Harness, Wagons and Vehicles

\section{HORSES AND MULES BOUGHT AND SOLD}

Good Milch Cows Always on Hand

We can get you some speed if you want it 


\section{No. 56}

\section{LENA SHIRLEY}

Pacer. Bay Finly. Foaled 1912. Standard and Registered. Consigned by A. H. Wingate, Avon, Illinois.

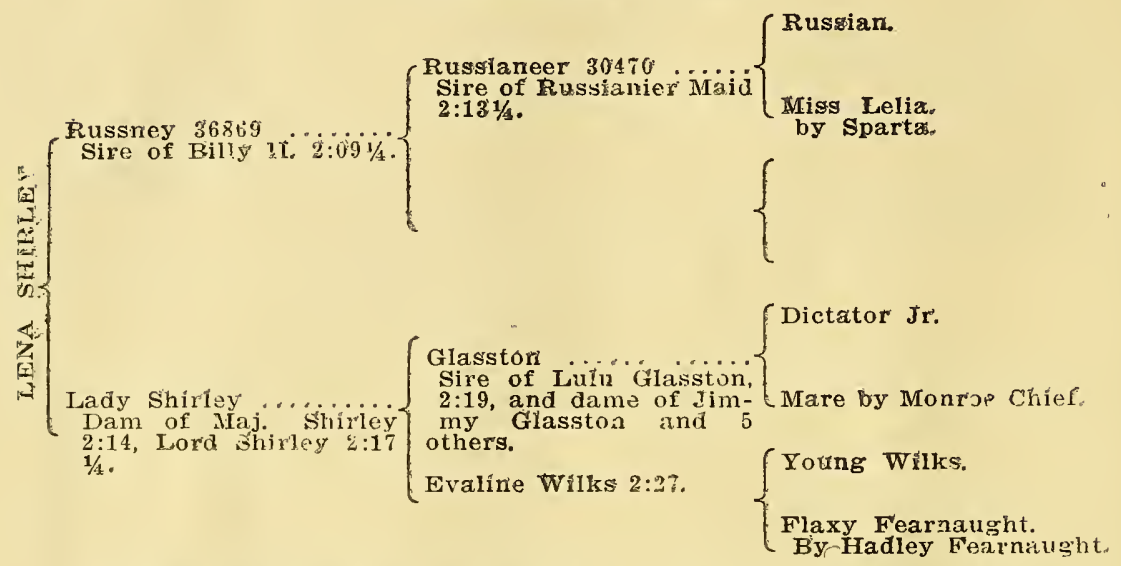

Owner's Statement-Lena Shirley is a beautiful large filly and will make a fast pacer, with handling. How can she help it? Sired by the sire of Billy $\mathrm{H}$. that cleaned up around here and acquired a record of $2: 191 / 4$ last year and her ajam has already produced two other fast ones. She's worth buying and saving.

All the stores advertise 1 in this catalogue are good placos to trade. 


\section{No. $57 / 5$ SCOTT AERITON}

Trotter. Chesnut gelding. Foaled 1909. Standard and Registered. Consigned by A. H. Wingate, Avon, Ill.

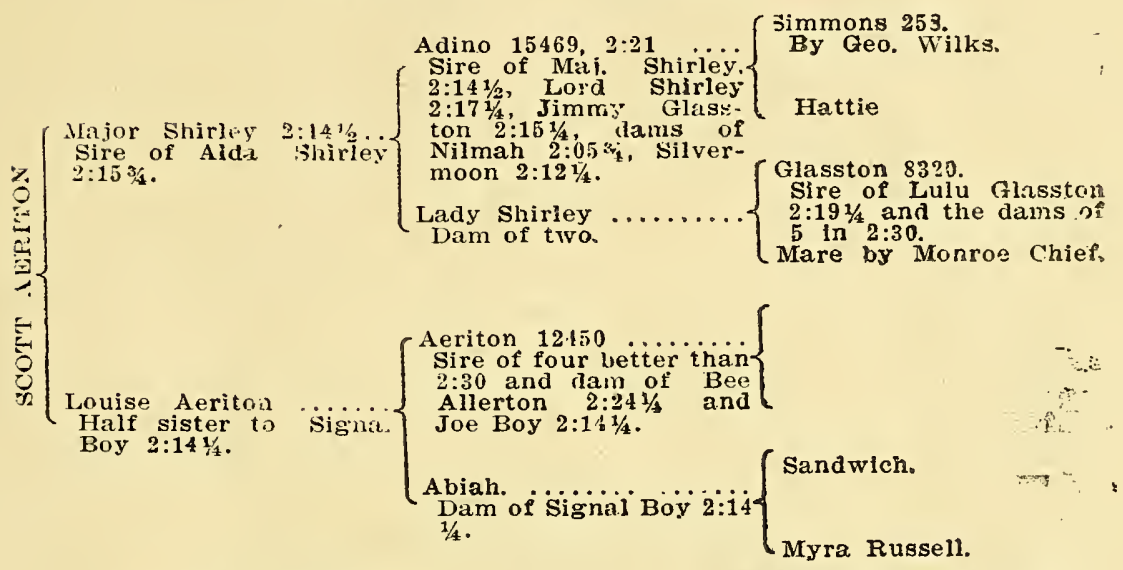

Owner's Statement-Scott Aeriton is a chesnut gelding and just the lind you have ben looking for if you want a fun horse or something to train and worth deveolping. $\mathrm{He}$ is a handsome fellow, having taken three ribbons in the show ring at the horse shows, is not afraid of automobiles and has been used as a family horse. He will make a trotter if trained and is just the kind any man wants who is looking for a highclass driver. 


\section{No. 58230 OLA MAY}

\section{Trial 2:11 1/2.}

Second six times. Retter. than 2:18.

The best prospect for the green paces in Central Illinois.

Pacer. Bay mare, 15.3. Foaled 1907. Bred by Henry Statt, Monmouth, Ill. Consigned by J. C. Canfield, Agent, Walnut Grove, Ill.

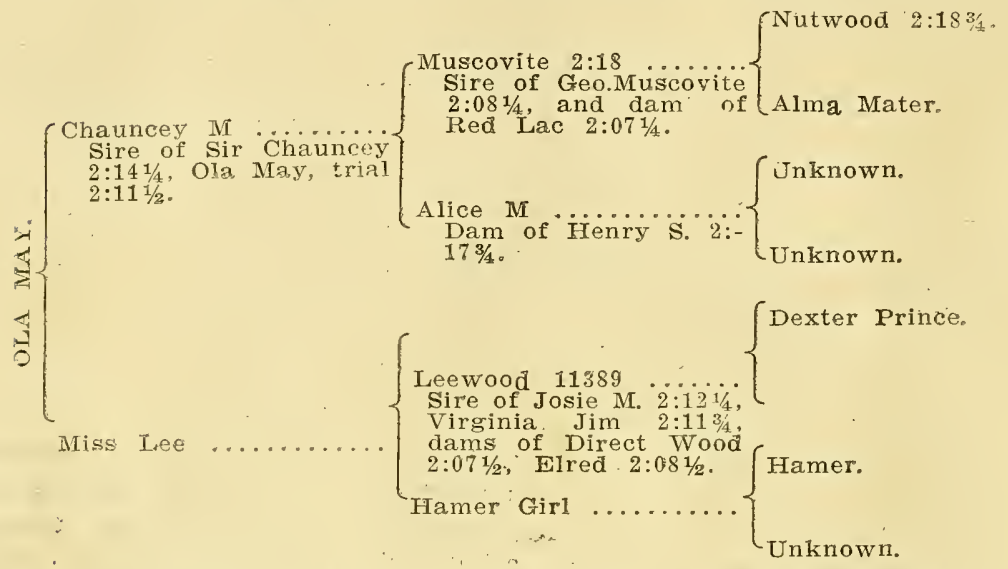

Owner.'s statement-Ola May is one of the best green pacers in Central Illinois. She has had two season's careful training and has been a mile in 2:11 $1 / 4$, last half in 1.03 . She was raced a few times last year for education and the summaries below speak for themselves. She is game, good headed, and can be placed anywhere. She is sound and all right in every way, and is a $2: 10$ pacer on a half-mile track in good hands. Sold for no fault, only owner wants to get out of the game. Here is the result of her two starts last season:

Griggsville, I1l., JuIy 25, 1912 .

\section{:20 Pace-Purse $\$ 300$.}

Jimmy Leaburn, b.g., G. W. Leaburn ......... 1 1 1

Ola May, b.in., by Channcy M ................ 22

Jimmy Glasston Jr., s,g., by Jimmy Glasston....2 33

Midnight, blk.

Jolly Girl .................... 55

Time $2: 171 / 4,2: 171 / 4,2: 18$.

Smithville, Mo., Oct. 2, 1912.-

\section{2:20 Pace-Purse $\$ 300$.}

Mamie Strath, b.m., by Strathberry ........ 11

Ola May, b.m., by Channcy $\mathrm{M} \ldots \ldots \ldots \ldots \ldots 2_{2}$

Patty Cake, b.m., by Rustic Wood ................. 3

Baby Bells, blk. m., by K. N. Bells ......... 45

Brownie .................... 5 . 4

Time $2: 17 \frac{1}{4}, 2: 171 / 4,2: 173 / 4$. 

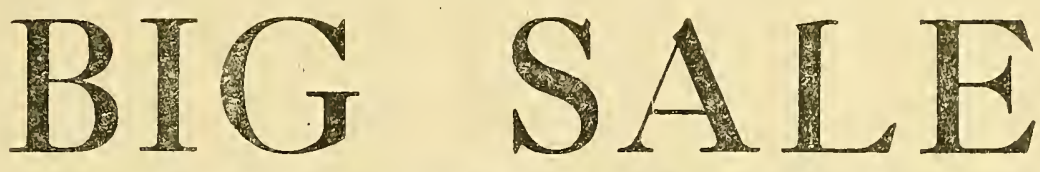

Vehicles $\left\{\begin{array}{l}\text { Dam .... Mother Earh } \\ \text { Sire . . . Old Hickory Nut }\end{array}\right.$

Buggips as low as $\$ 40.00$

Road Wagons as low as $\$ 35.00$

Carriages as low as $\$ 75.00$

Horse Furnishing Goods of all kinds. Harness, all kinds.

Wagons, $\$ 70.00$ to $\$ 80.00$.

Osborn Harrows.

Osborn Discs.

McCormick Binders, Mowers and Rakes.

Manure Spreaders. Cream Seperator. Terms: Day of Sale

C. N. R. RAMRH 20), 202, 204, 206, 208 South Lafayett si MACOMB, ILLINOIS 


\section{No. 59//ל MAY SHIRLEY}

rrotter. Chestnut filly; 15.1. Foaled 1910. Bred by Geo. W. Canfield, Avon, IIl. Consigned by J. C. Canfield, Walnut Grove, Ill.

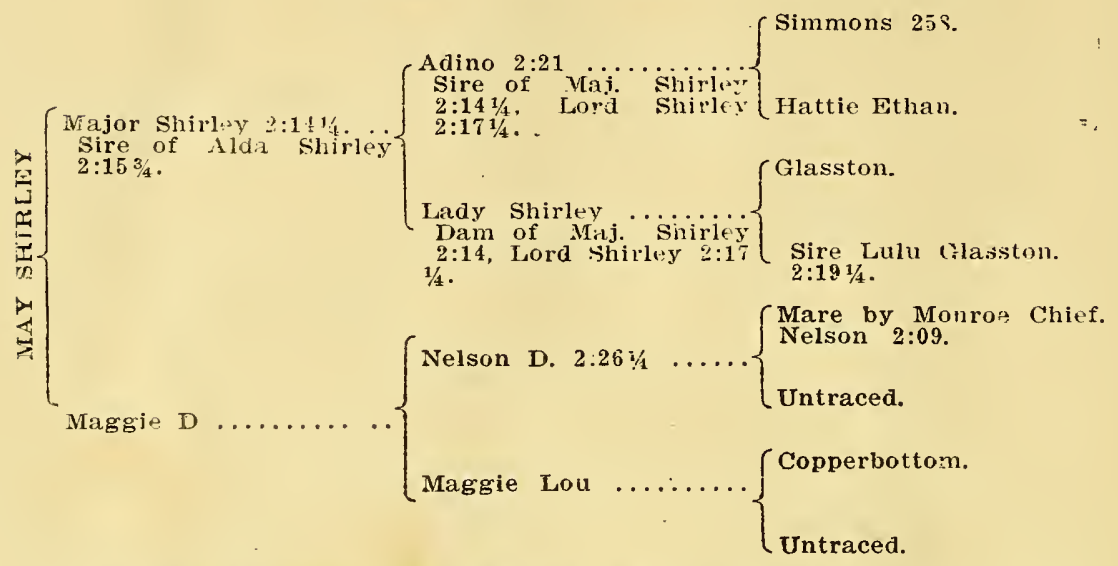

Owner'sStatement- May Shirley is a handsome filly, just nicely broken; has a nice way of going acts like she would learn to trot. Will make a nice road mare, as she has a good disposition an.l plenty of style.

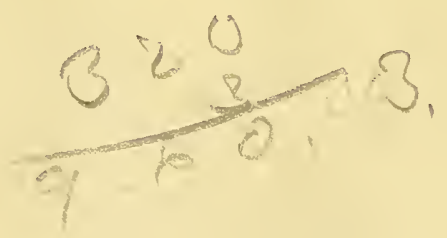

Femember the auction commences at 12 o'clock sharp. 


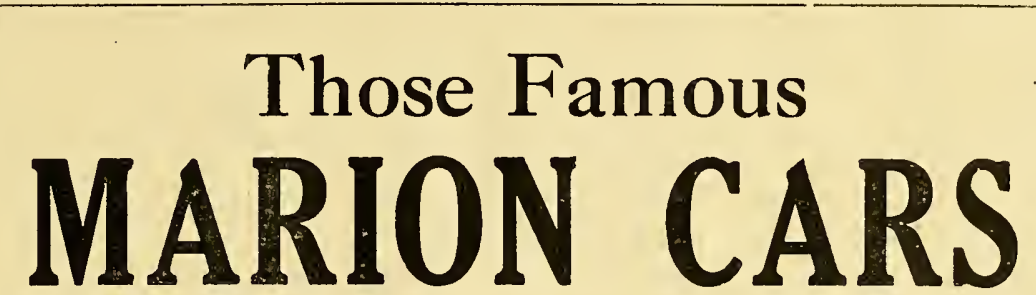

This popular car is now being handled in Macomb and vicinity, and it will pay everyone intending to purchase a new machine to investigate this car.

\section{The Marion 37-A}

The Marion $37-A$ is a large, delightfully rooms. easy riding car for five leople. It has all the refinements which nodern methods maire possibie, and the most compious and luxurious equipment which the market affords. It i: a big car-big in quelity size, and efficiency, and se!1.3 at $\$ 1475$.

\section{The Marion 48-A}

The Marion $48-A$ is a $48-$ horsepower car de luse, with electric self-starter, lighting system, horn, a's! cumplete equipment. Becausa il is ionger, roomier and more powerful, it is not oals an unquestioned leader amons cars of its own price, but it immediately compares with mucin mire expensive products. P'urc'?asing and manufacturıng facilities and superior manaizement have made the five pissenger Marion 48-A towine car possible for $\$ 1850$.

\section{SID CARNAHAN, Agent Headquarters at M. \& A. Garage}




\section{No. 60}

\section{FAMOUS}

Shire Stallion. Black. Pure bred, A-4390. Consigned by J. D. Tabler, Piymouth, Ill. Foaled Aprí 10, 1897. Bred by

W. E. Bates, Alexandria, Mo.

Sired by Blackfoot 1821 (6712). Dam, Snap Dragon 1818, Vol. XI., by Collegian 3559 .

Orner's Statement-Famous is a splendid medium weight type of draft horse, of fine appearance and best of action. He is a first-class, reliable breeder and will give the best of satisfaction to whoever purchases him.

Nos. 61, 62, 63, 6t, 65 Reserved.

\section{Blount's}

\section{Shoes}

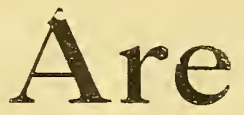

Better

\section{North Side Square Macomb, Ill.}

All the stores advertise.1 in this catalogue are good places to trade. 



\section{Grand

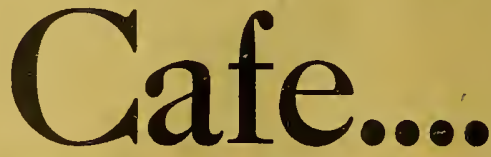

and

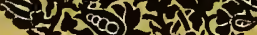

.

.

The only place in Macomb serving anything You want in the way of eatables....

Horsemen especially invited day of sale....

West Side Square

Gary A dcock Proprietor 